\title{
Dobór optymalnej rozdzielczości sekcji sejsmicznej w drodze analizy i modyfikacji charakterystyk spektralnych danych sejsmiki powierzchniowej i otworowej
}

\begin{abstract}
W artykule zaprezentowano podstawy teoretyczne i metodykę poszerzenia i modyfikacji charakterystyki spektralnej sekcji sejsmicznej. Przykłady praktyczne realizowane na materiałach polowych, zarejestrowanych w rejonie występowania formacji łupkowych w Polsce, potwierdzają użyteczność zaproponowanego rozwiązania w bieżących projektach.

Słowa kluczowe: rozdzielczość danych sejsmicznych, kompleksowa charakterystyka spektralna, prosta i odwrotna transformacja Fouriera, modyfikacja spektralna.
\end{abstract}

\section{The choice of optimal resolution of seismic data for given geological objects through the application of borehole velocity measurement for spectral modification}

\begin{abstract}
In the article the basic principles for the improvement of seismic data resolution are presented. Special attention is paid to the correlation of geological target parameters. Practical examples implemented on field materials registered in the area of shale formation in Poland confirm the usefulness of the proposed solution in current projects.
\end{abstract}

Key words: resolution of seismic data, complex spectral characteristics, direct and inverse Fourier transformation, spectral modification.

\section{Wprowadzenie}

Obserwowane ostatnio w historii poszukiwań węglowodorów mniej lub bardziej długookresowe ukierunkowania na eksplorację wybranych, często nietypowych, obiektów geologicznych zazwyczaj skutkują pojawieniem się nowych rozwiązań i sposobów umożliwiających najwierniejszą charakterystykę złożową tych obiektów oraz ocenę ich potencjału zasobowego.

W powyższym aspekcie minione dziesięciolecie określić można na świecie okresem „boomu łupkowego”. Sukcesy ekonomiczne, jakimi zaowocowały odkrycia gazu w formacjach łupkowych w Ameryce Północnej, znalazły silny oddźwięk również w Polsce $[10,15]$. Jakkolwiek osiągnięć poszukiwawczych nie można było oczekiwać, chociażby ze względu na nieporównywalnie trudniejszą lokalizację (znacznie głębiej) gazonośnych formacji łupków sylurskich, trend łup- kowy w Polsce zaznaczył się pozytywnie - rozwojem wielu nowych koncepcji i oceną ich przydatności w warunkach krajowych lub, ewentualnie, wdrożeniem adaptowanych rozwiązań zagranicznych.

Jedną z koncepcji, stosowanych szczególnie w Stanach Zjednoczonych, która została rozpracowana w ramach realizowanego programu Blue Gas (projekt GASŁUPSEJSM, zadanie 2, pt. Poszukiwanie, rozpoznawanie-modelowanie i przetwarzanie danych sejsmicznych, $w$ tym metodyka określania żadanej rozdzielczości sejsmicznego pola falowego $w$ procesie lokalizacji, udostępniania i eksploatacji formacji łupkowych), jest koncepcja sejsmiki szerokiego zakresu częstotliwości, znana na świecie jako tzw. broadband seismics. Spektrum częstotliwości obecnych w zarejestrowanym metodą sejsmiczną polu falowym stanowi podstawowy czynnik 
wpływający na rozdzielczość danych sejsmicznych, a więc w efekcie na wynik końcowy interpretacji geologicznej.

Zagadnienie rozdzielczości danych sejsmicznych silnie akcentowane jest $\mathrm{w}$ problematyce poszukiwania gazu w formacjach łupkowych, co wynika z faktu, że gazonośne formacje łupkowe to najczęściej bardzo cienkowarstwowe przeławicenia o dużej poziomej heterogeniczności.

Aby odtworzyć ten rodzaj ośrodka i zbudować jego model geologiczny, niezbędna jest sejsmika wysokiej rozdzielczości i wysokorozdzielcze pole falowe, na którym zidentyfikować można subtelne zmiany w ośrodku geologicznym, tak aby przedstawiony wynik interpretacji był najbardziej konsystentny z rzeczywistym obrazem geologicznym i możliwie jedynym odpowiadającym panującym w ośrodku regułom danego basenu sedymentacyjnego.

Z praktyki wiadomo, że obraz falowy przetworzony nieadekwatnie do geologii najczęściej skutkuje wieloma postaciami interpretacji, a wybór tej właściwej jest trudny ze względu na wieloznaczność pozornie poprawnych wyników. Objaśnienia wymaga sformułowanie „obraz falowy przetworzony nieadekwatnie do geologii”, bowiem w chwili przystępowania do przetwarzania najczęściej wiedza a priori o ośrodku jest bardzo skąpa (lub żadna). „Adekwatność do geologii” oceniana jest na modelach teoretycznych poprzez porównanie wyników modelowania sejsmicznego oraz wyników na danych polowych.

W zaproponowanym przez autorów rozwiązaniu informacje o ośrodku określone są w domenie spektralnej w postaci widma amplitudowego i fazowego, a podobieństwo uzy- skiwanych wyników i realiów analizowanego ośrodka geologicznego oceniane jest na podstawie stopnia rozbieżności charakterystyk spektralnych danych sejsmiki powierzchniowej i otworowej.

Wzbudzone różnymi metodami (dynamit, vibroseis, airgun) na powierzchni wzbudzenia sejsmiczne pole sprężyste w wyniku propagacji drgań w ośrodku geologicznym podlega procesom tłumienia i pochłaniania, co skutkuje między innymi zanikiem niektórych częstotliwości w polu sprężystym, obserwowanym sejsmicznie i zapisanym na powierzchni obserwacji przez aparaturę sejsmiczną. Proces ten najsilniej uwidacznia się w zakresie najwyższych częstotliwości widma amplitudowego. Standardowo rejestrowane i przetwarzane dane sejsmiczne, w użytecznym przedziale charakterystyki spektralnej, często nie zawierają częstotliwo-

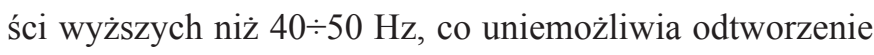
szczegółów budowy geologicznej, wymaganych przez potrzeby współczesnej eksploatacji złóż węglowodorów i innych zasobów naturalnych.

Zasadność powyższego stwierdzenia pokazana została w kolejnym rozdziale. Dla uproszczenia rozumowania przytoczę nieco zmienioną definicję „rozdzielczości”, podaną w słowniku R.E. Sheriffa (1973) [20], określonej jako zdolność rozdzielenia dwóch cech znajdujących się bardzo blisko siebie (zarówno w sensie wielkości numerycznej, jak i geometrii) lub równoznacznie - jako najmniejsza zmiana w zapisie danych wejściowych, powodująca mierzalną zmianę w zapisie danych wyjściowych.

\section{Relacja prędkość-częstotliwość-miąższość. Wybrane założenia metodyczne}

Zagadnienie rozdzielczości sekcji sejsmicznej nie jest zagadnieniem nowym ani aktualnie implikowanym przez „,boom łupkowy”, związany z poszukiwaniem węglowodorów w formacjach łupkowych. Jako dowód przytoczyć tu można artykuł pt.: How thin is a thin bed, opublikowany w „Geophysics" w grudniu 1973 r. [22]. Artykuł został przedrukowany z „Proceedings - Geophysical Society of Tulsa”, gdzie ukazał się jeszcze wcześniej (1957-1958). Edytorzy posłużyli się taką niecodzienną praktyką ze względu na wagę postawionego tam zagadnienia.

W cytowanej publikacji autor M.B. Widess definiuje cienką warstwę (w optyce sejsmicznej), wykorzystując zdolności odbijające ośrodka geologicznego (reflective properties), jako taka, której miąższość jest mniejsza niż $\lambda_{b} / 8$, gdzie $\lambda_{b}$ jest dominującą długością fali, obliczoną z wykorzystaniem prędkości propagacji sprężystej fali sejsmicznej w tej warstwie. Według wspomnianego autora przybliżona ocena amplitudy odbicia od cienkiej warstwy może być przeprowadzona z wykorzystaniem relacji:

$$
A_{\text {thin }}=\frac{4 \pi A b}{\lambda_{b}}
$$

gdzie: $b$ jest miąższością warstwy, zaś $A$ jest amplitudą refleksu w przypadku, gdy warstwa jest bardzo gruba.

M.B. Widess podaje uproszczone i wygodne w stosowaniu formuły, które umożliwiają obliczanie amplitudy odbicia od cienkiej warstwy.

$R_{1} \cong-A \cos \left(t+\frac{B}{V_{B}}\right) \frac{2 \pi}{\tau}-R_{2} \cong-A \cos \left(t-\frac{B}{V_{B}}\right) \frac{2 \pi}{\tau}(2)$

gdzie:

$\tau$ - okres dominujący sygnału,

$B$ - miąższość warstwy,

$V_{B}$ - prędkość propagacji fali sprężystej w warstwie $B$.

Definiując różnicę między współczynnikami odbicia $R_{1}$ i $R_{2}$ jako $R_{d}$, otrzymujemy oszacowanie zmiany wielkości współczynnika odbicia podczas propagacji przez cienką warstwę: 


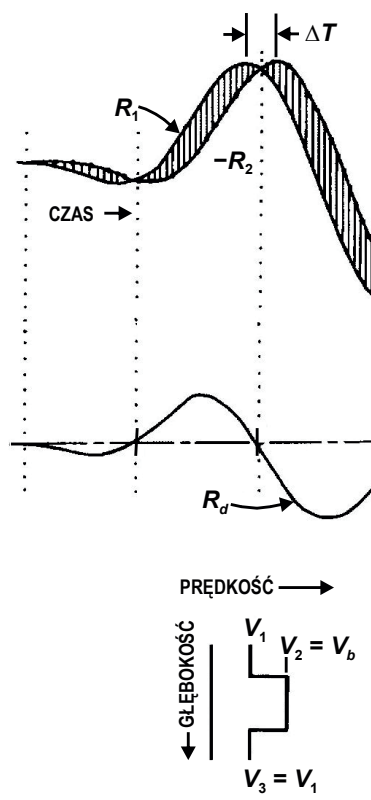

ROZKLAD PRĘDKOŚCI

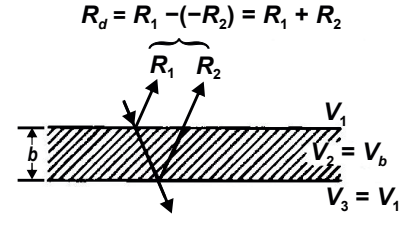

PRZEBIEG PROMIENIA ODBITEGO

Rys. 1. Diagram promieniowy i określenie współczynnika odbicia (według M.B. Widessa; zmienione)

$$
R_{d}=R_{1}+R_{2} \cong\left[2 A \sin 2 \pi B / \tau V_{B}\right] \sin 2 \pi t / \tau
$$

gdzie: $R_{1}, R_{2}$ - współczynniki odbicia uwzględniające kształt sygnału.

Amplituda odbicia od warstwy cienkiej jest w przybliżeniu proporcjonalna do miąższości warstwy i odwrotnie proporcjonalna do długości fali. Warstwa, która jest „cienka” dla jednej częstotliwości, niekoniecznie jest cienka dla częstotliwości innej, np. wyższej.

Przyjmując najprostsze relacje kinematyczne dla procesu propagacji:

$$
\begin{gathered}
R E S=f(v) \\
\lambda=\tau \cdot V=\frac{V}{v}=\frac{1}{K} \\
V=f(v) \\
s=t \cdot V \\
\tau=\frac{1}{v}
\end{gathered}
$$

gdzie:

$R E S$ - rozdzielczość,

$v$ - częstotliwość [Hz],

$\lambda$ - długość fali [m],

$K-$ liczba falowa,

$V$ - prędkość propagacji fali sprężystej [m/s],

$s$ - droga propagacji fali sprężystej [m],

$t$ - czas propagacji fali sprężystej [s],

$\tau$ - okres fali [s],

Tablica 1. Sekwencja obliczania długości fali $\lambda=\tau \cdot V$

\begin{tabular}{|c|c|c|c|}
\hline $\begin{array}{c}\text { Częstotliwość } v \\
{[\mathrm{~Hz}]}\end{array}$ & $\begin{array}{c}\text { Okres } \\
\text { fali } \\
\tau=1 / \nu\end{array}$ & $\begin{array}{c}\text { Długość fali }[\mathrm{m}] \\
\text { dla } V=2000 \mathrm{~m} / \mathrm{s}\end{array}$ & $\begin{array}{c}\text { Długość fali }[\mathrm{m}] \\
\text { dla } V=4000 \mathrm{~m} / \mathrm{s}\end{array}$ \\
\hline 10 & 0,10 & 200 & 400 \\
\hline 20 & 0,05 & 100 & 200 \\
\hline 50 & 0,02 & 40 & 80 \\
\hline 100 & 0,01 & 20 & 40 \\
\hline
\end{tabular}

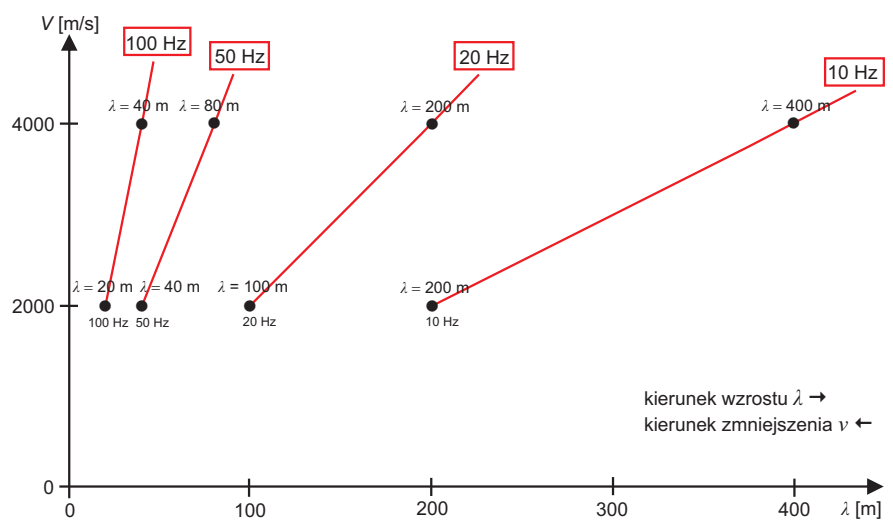

Rys. 2. Wykres zależności $\lambda=f(V, v)$

łatwo obliczamy osiągalne rozdzielczości w zależności od wielkości prędkości propagującej fali $V$ (tablica 1).

Z powyższego wynika, że dla analogicznych częstotliwości długość fali maleje wraz ze zmniejszaniem prędkości propagacji fali sejsmicznej.

Proste przedstawienie odbicia od warstwy cienkiej zilustrować można jak na rysunku 3.

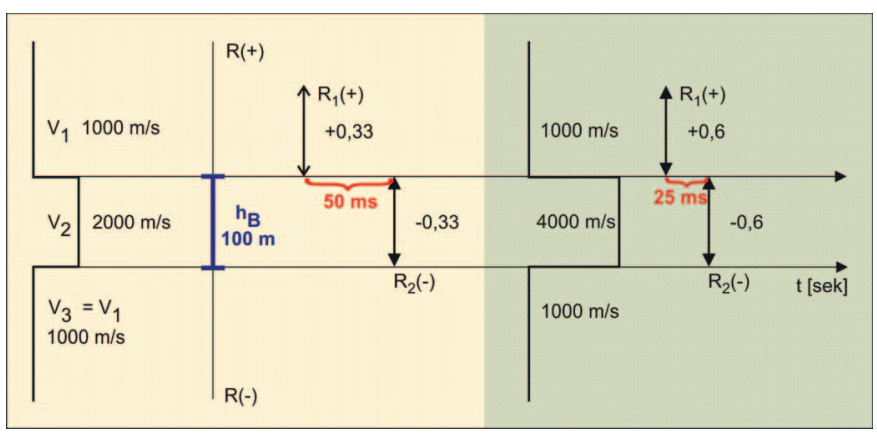

Rys. 3. Zależność opóźniania refleksu odbitego od spągu warstwy cienkiej w zależności od prędkości propagacji fal w warstwie cienkiej

Obliczenie współczynnik odbicia $R$ realizowane jest prostą formułą:

$$
\begin{array}{ll}
R=\frac{\rho_{2} V_{2}-\rho_{1} V_{1}}{\rho_{2} V_{2}+\rho_{1} V_{1}} & 0<R \leq-1, \text { gdy } V_{2}<V_{1} \\
& 0<R \leq 1, \text { gdy } V_{2}>V_{1}
\end{array}
$$


Warstwę o miąższości $100 \mathrm{~m}$ (w przypadku odbicia pionowego - normal incidence) fala sprężysta o prędkości propagacji $2000 \mathrm{~m} / \mathrm{s}$ pokonuje w czasie $50 \mathrm{~ms}$. Stąd odbicie od spągu analizowanej warstwy $B$ opóźnione będzie w stosunku do odbicia od stropu tej warstwy o czas (tzw. podwójny) równy $100 \mathrm{~ms}$. Dla odbicia pionowego i fali o częstotliwości $10 \mathrm{~Hz}$ oraz prędkości $V_{p}=2000 \mathrm{~m} / \mathrm{s}-$ okres tej fali $=100 \mathrm{~ms}$. Jeżeli pokonanie miąższości $100 \mathrm{~m}$, w tym przypadku, spowoduje opóźnienie odbicia (refleksu) o $50 \mathrm{~ms}$, to po czasie równym okresowi $2 T$ będziemy obserwować interferencję konstruktywną (wzrost amplitudy maksymalnej). W czasie równym połowie okresu dochodzi do interferencji destruktywnej, w skrajnym przypadku do zaniku amplitud drgania.

Analogicznie dla fali o prędkości propagacji $V_{p}=4000 \mathrm{~m} / \mathrm{s}$ długość fali będzie wynosić $400 \mathrm{~m}$, a okres będzie nadal $100 \mathrm{~ms}(v=10 \mathrm{~Hz})$. Pokonanie miąższości $100 \mathrm{~m}$ spowoduje opóźnienie refleksu o $25 \mathrm{~ms}$ (50 ms czasu podwójnego).
Rysunek 4 pokazuje rolę częstotliwości w poprawnym odtworzeniu geometrii ośrodka, w zależności od istniejących parametrów fizycznych.

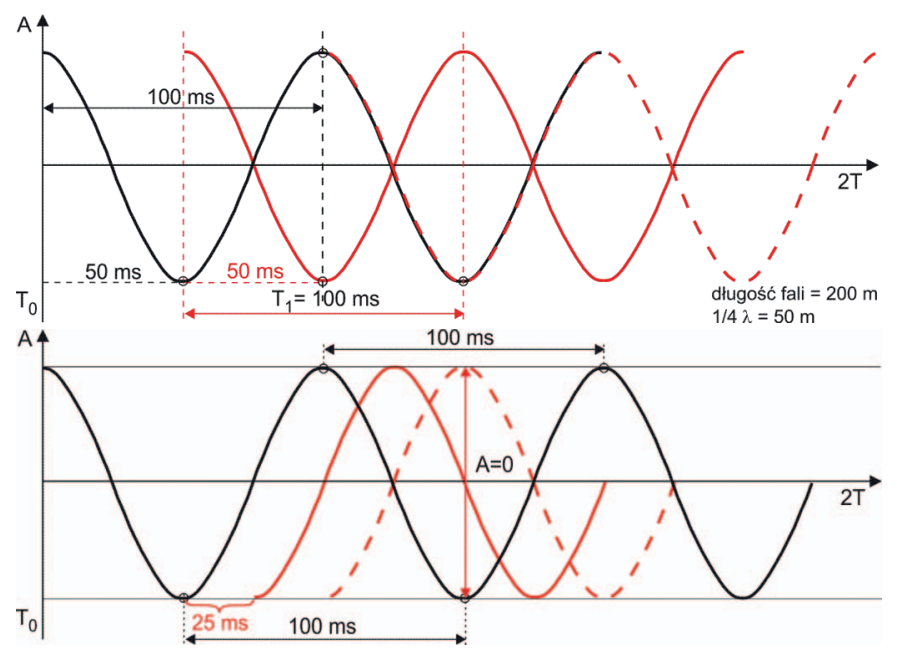

Rys. 4. Przykład tworzenia układu interferencji konstruktywnej i destruktywnej

\section{Wybrane zagadnienia matematyczne. Prosta i odwrotna transformacja Fouriera}

W niniejszej publikacji jako koncepcję rozwiązania tytułowego zadania przyjęto doprowadzenie rozdzielczości sekcji sejsmicznej (bez względu na rodzaj akwizycji i etap przetwarzania - rekordy pojedyncze, sumy) do rozdzielczości możliwie najbliższej do profilowań otworowych (najczęściej profilowanie akustyczne, ale nie wyłącznie).

Opracowane algorytmy i programy realizowane są w domenie spektralnej (spektrum zespolone) i wykorzystują funkcje refleksyjności obliczone $\mathrm{z}$ danych otworowych lub, w przypadku małej liczebności otworów, z sejsmogramów teoretycznych, konsystentnych z danymi sejsmicznymi. Danymi wejściowymi i wyjściowymi są pliki w formacie SEG-Y.

Jak wynika z powyższego zdefiniowania koncepcji, bardzo ważny element $\mathrm{w}$ sekwencji algorytmicznej stanowią analizy charakterystyk spektralnych, zarówno danych sejsmicznych, jak i danych otworowych, realizowanych przemiennie w domenie głębokościowej i w domenie czasowej. Podstawowe procedury wykorzystują znane relacje $\mathrm{z}$ analizy szeregów czasowych - prostą i odwrotną transformację Fouriera. Jeżeli:

dowolną trasę sejsmiczną $X(t)$ poddamy transformacji Fouriera według relacji

$$
\begin{aligned}
F F T(X(t)) & =\int_{-\infty}^{\infty} X(t) e^{-j \omega t} d t= \\
& =A^{*}(\omega)\left[\cos \left(\phi^{*}(\omega)\right)-j \sin \left(\phi^{*}(\omega)\right)\right]
\end{aligned}
$$

oraz analogicznie funkcję refleksyjności $R_{c}(t)$

$$
\begin{aligned}
F F T\left(R_{c}(t)\right) & =\int_{-\infty}^{\infty} R_{c}(t) e^{-j \omega t} d t= \\
& =A^{* *}(\omega)\left[\cos \left(\phi^{* *}(\omega)\right)-j \sin \left(\phi^{* *}(\omega)\right)\right]
\end{aligned}
$$

to ich transformaty postaci $X(\omega)$ oraz $R_{c}(\omega)$ opisują zespolone charakterystyki spektralne, gdzie $A^{*}(\omega)$ i $\phi^{*}(\omega)$ to widma amplitudowe i fazowe trasy wejściowej (INPUT) $X(t)$, zaś $A^{* *}(\omega)$ i $\phi^{* *}(\omega)$ to widma amplitudowe i fazowe funkcji refleksyjności $R_{c}(t)$, utworzonej na podstawie pomiaru profilowania akustycznego w otworze.

Odwrotna transformacja Fouriera $F F T^{-1}$ realizuje przejście z domeny spektralnej do domeny czasowej (standardowej domeny rejestracji w metodzie sejsmicznej) według relacji jak niżej:

$$
\begin{gathered}
F F T^{-1} X(\omega)=X(t)=\int_{-\infty}^{\infty} X(\omega) e^{j \omega t} d \omega \\
F F T^{-1} R_{c}(\omega)=R_{c}(t)=\int_{-\infty}^{\infty} R_{c}(\omega) e^{j \omega t} d \omega
\end{gathered}
$$

Analiza porównawcza kształtu i parametrów widm trasy $X(t)$ oraz funkcji refleksyjności $R_{c}(t)$ stanowi podstawę do zdefiniowania parametrów widm $A^{\circ}(\omega)$ i $\phi^{\circ}(\omega)$ operatora modyfikacji spektralnej, uwzględniającego różnice w charakterystykach spektralnych danych pochodzących z dwóch źródeł - rejestracji sejsmiki powierzchniowej i otworowej. 
Modyfikację spektralną pola sejsmicznego realizujemy prostymi operacjami w domenie spektralnej:

$$
\begin{array}{ll}
A_{m}(\omega)=A^{*}(\omega) \cdot A^{\circ}(\omega) & \omega(0, \mathrm{Nq})[\mathrm{Hz}] \\
\phi_{m}(\omega)=\phi^{*}(\omega)+\phi^{\circ}(\omega) & N_{q}=\frac{1}{2} d t
\end{array}
$$

gdzie:

$A_{m}(\omega)$ i $\phi_{m}(\omega)$ to widma amplitudowe i fazowe trasy wynikowej (OUTPUT) po modyfikacji spektralnej, $d t-$ krok próbkowania $[\mathrm{s}]$.
Powrót do domeny czasowej dokonuje się ponownie poprzez $F F T^{-1}$.

Powyższa koncepcja implikuje wykorzystanie modelu prędkościowego, utworzonego na podstawie obliczenia inwersji sejsmicznej, której wyniki - w postaci impedancji akustycznej - umożliwiają konstrukcję sejsmogramów teoretycznych oraz - w postaci pola prędkości w funkcji głębokości - pozwalają na dobór zakresu częstotliwości pola sejsmicznego, zapewniającego najlepszą konsystencję danych sejsmicznych i otworowych.

\section{Schemat logiczny i logistyczny rozwiązania zagadnienia zwiększenia rozdzielczości sekcji sejsmicznych}

Przedstawioną powyżej sekwencję obrazuje rysunek 5.

Głównymi modułami opracowanego systemu są:

- program startowy o nazwie PREDOPE2 - realizujący analizę obrazu falowego oraz określenie operatora predykcji;

- program główny o nazwie HRMSTAND - realizujący modyfikację obrazu falowego, obliczenie modyfikacji danych sejsmicznych wynikających z określonego operatora oraz podprogramy o nazwach ILWIDTRB i ILWIDTRH - realizujące optymalizację parametrów operatora; - programy wspomagające o nazwach NaPetrel oraz ExpSEGY - pozwalające na konwersję danych, poprzez wybór wskazanego profilu sejsmicznego z kostki 3D zapi- sanej w formacie SEG-Y, i przedstawienie w opcji profili 2D, wraz z transformacją formatu SEG-Y do pliku binarnego I2 i REAL oraz transformacją plików binarnych (I2, REAL) do formatu SEG-Y, umożliwiającego wprowadzenie wyników obliczeń do systemu PETREL, jak też wizualizację graficzną za pomocą posiadanego oprogramowania. Celem tych programów jest zapewnienie pełnej swobody realizacji obliczeń w języku FORTRAN i transformację wyników do standardów obowiązujących w polskim i światowym przemyśle nafty i gazu (w tym, szczególnie, wykorzystanie możliwości wizualizacyjnych systemu PETREL).

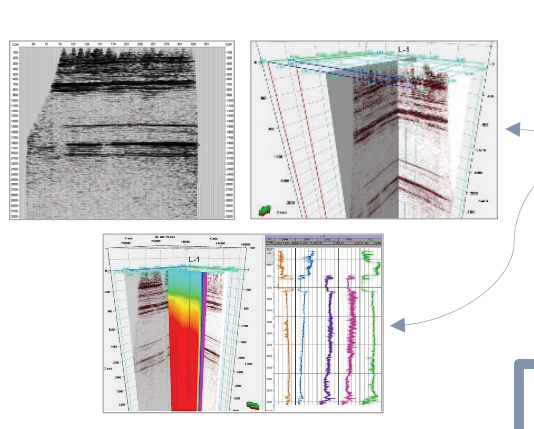

Obliczenie charakterystyk spektralnych $A(f), \varphi(f)$
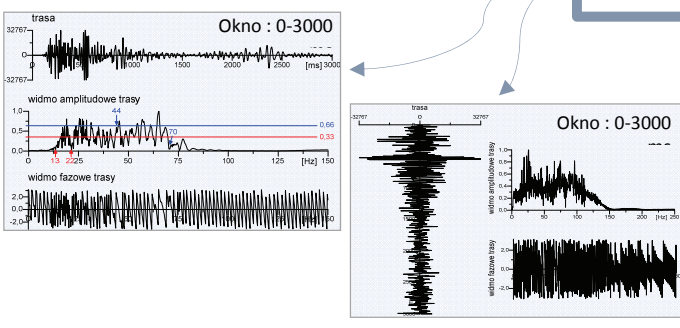

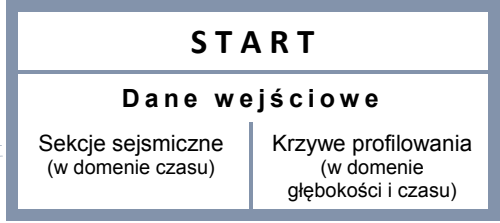

Sekcja sejsmiczna

Wybór trasy (WIDTRSA) Wybór trasy (WIDTRSA)
Wybór okna A (OKNAP)

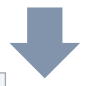

.
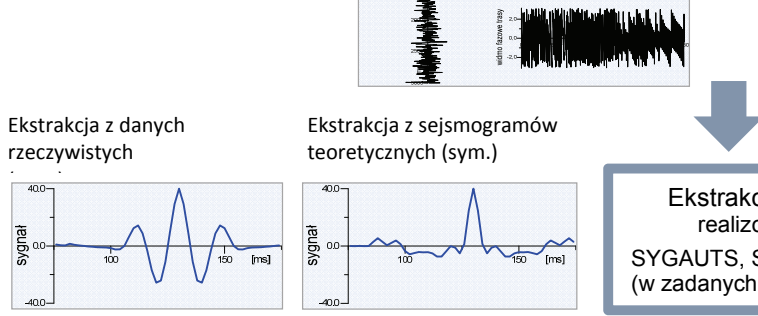

Ekstrakcja z sejsmogramów teoretycznych (sym.)

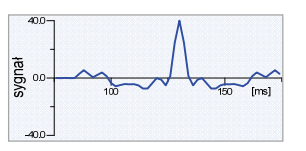

Ekstrakcja sygnałów i obliczenie widm FA realizowane procedurami zewnętrznymi: SYGAUTS, SFAUTOA WIDMOA, WAVLETA, FAZAA (w zadanych oknach 1A, 2A, .....)
Realizacja w sekwencji tras
(petla wg liczby tras

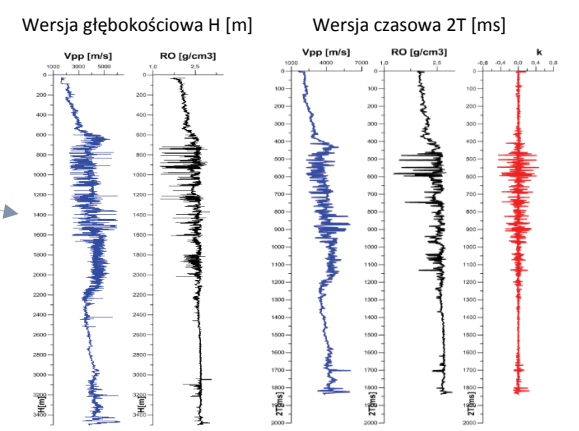

Krzywe profilowania Przejście do domeny czasu $\rho, v(h) \rightarrow \rho, v(2 \mathrm{~T})$ Obliczenie krzywej refleksyjności Rc (2T) (WOTWORHP)

Moduly przygotowania danych dla programu PREDOPE2

Określenie sygnatów metoda CEPSTRUM programen SYGAUTS, z uwzglednieniem przesuniecia fazowe $\phi=\phi_{g}(1-2 R / N)$ w stosunku do fazy glównej gdzie:

$\phi_{g}$ - faza glówna

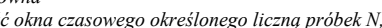
w którym dokonuje sie korekcji fazowej

- wartość z przedzialu $\{0, N\}$ przyjęta do korekcji fazy $R \leq N / 2 \rightarrow$ w wyniku sygnat minimalnofazowy $R=N / 2 \rightarrow w$ wyniku sygnat zerofazowy symetryczn $R \geq N / 2 \rightarrow w$ wyniku sygnal maksymalnofazowy 

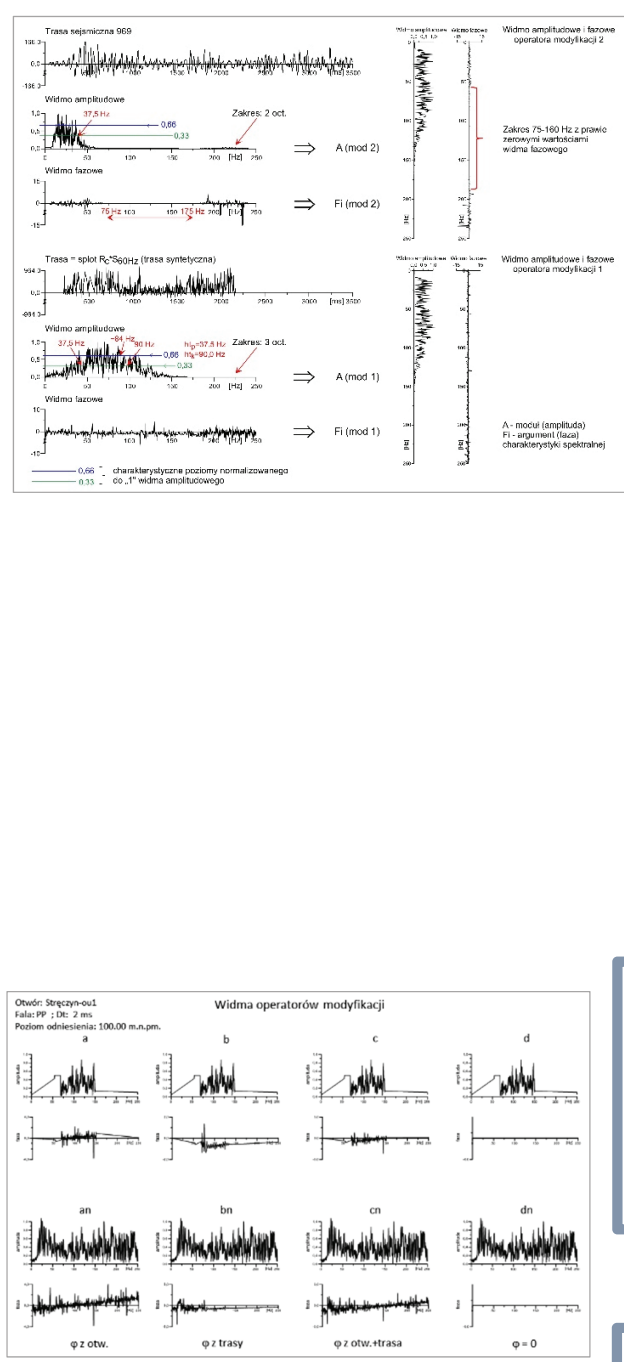

przed modyfikacja
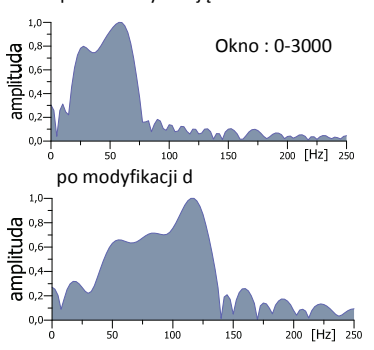

po modyfikacji dn

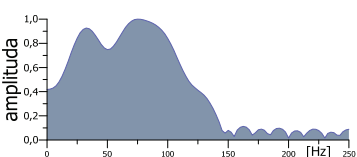

Obliczone sygnały

liczba

sygnatón

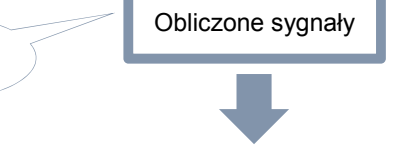

Obliczanie sejsmogramu teoretycznego podprogramem SPLOTOTW

deklarowanym w programie głównym PREDOPE2

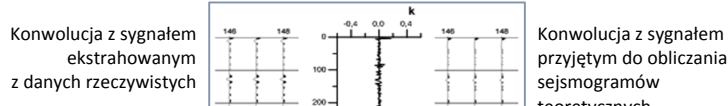

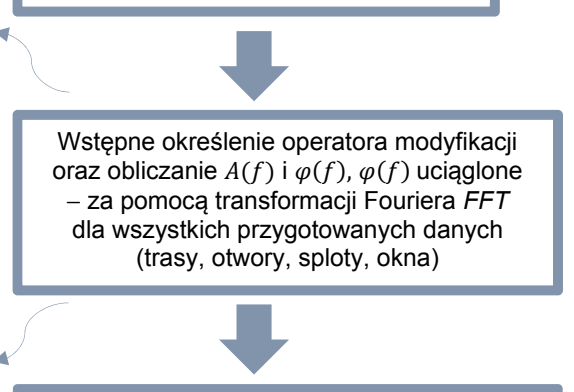

Wyprowadzenie wyników pośrednich (.DAT) Wykorzystanie zewnętrznych programów graficznych, np. GRAPHER

Określenie wskazanych parametrów przewidywanego operatora modyfikacji

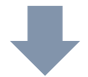

(2)

\section{Selekcja wybranych parametrów:}

- Okno czasowe trasy i otworu

- Wybór chcianych przedziałów częstotliwości oraz poziomu wynikowego widma amplitudowego

w zakresie $\{0 \div 1\}$ - widma znormalizowanego

- Wyznaczenie wartości zespolonego widma operatora modyfikacji spektralnej i ocena wyników

Wyniki obliczenia zespolonej charakterystyki spektralnej operatorów modyfikacji sejsmicznego pola falowego w zależności od założonego a priori sposobu określenia widma fazowego $\varphi(f)$ i przy ustalonym a priori sposobie obliczenia widma amplitudowego $A(f)$

Obliczone amplitudowe widmo operatora modyfikacji spektralnej stanowi wejście do kolejnej procedury - program HRMSTAND wraz ze wskazanym widmem fazowym

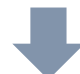

Definiowanie opcji operatora modyfikacji $a \quad b \quad c \quad d$

w zależności od sposobu wyboru danych wejściowych (trasa + otwór) $A(f), \varphi(f)$
Obliczanie programami PREDWID, SKLWIDM (skladanie widma amplitudowego) lub liczenie iloczyn ILWIDP, ZMIAWIDP, PODWIDMP

Akceptacja wybranych parametrow operatora TAK (OK) NIE (ZMIAWIDP)
Podnoszenie widma zespolonego operatora modyfikacji spektralnej trasy z sekcji sejsmicznej wejściowej (w pliku HRMSTAND dan

(dot. każdej trasy, aby uniknać obecności $\boldsymbol{A}(f)=0$ ) + parametry pobrane z pliku DANE:

dlugość trasy $\mathrm{N}$ (w próbkach), krok próbkowania, czas poczatkowy, czas końcowy, $n$ r 1. trasy 
Wybór wariantu akwizycji i przetwarzania danych sejsmicznych INPUT

W3 $\ldots$ warianty zastosowanego
W1 1. schematu akwizycji
W3 - krotność $\sim 469$
W1 - krotność $\sim 2680$

Postać danych wejściowych - POSTACK TIME DEPTH .............

W3 (akwizycja)_opcja 1 (modyfikacja spektralna) after stack

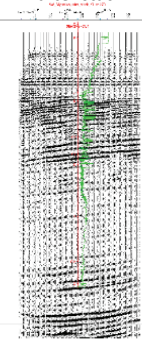

$$
\text { sxl270a }
$$

sxl270d

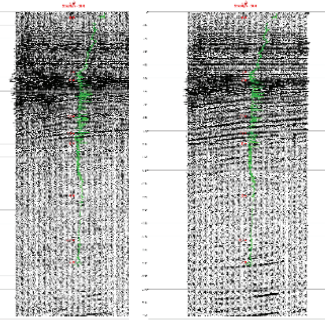

W1 (akwizycja)_opcja 2 (modyfikacja spektralna) after stack sxl270an sxl270dn
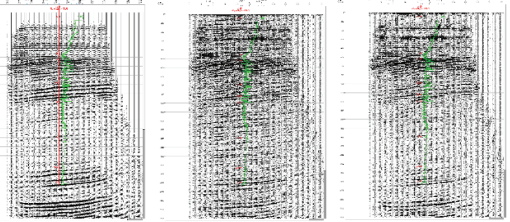

Przejście z domeny spektralnej do domeny czasowe (wykorzystanie odwrotnej transformacji Fouriera)

Spectrum $(f) \Rightarrow$ Trasa (2T) i plik I2 z bezpośrednim dostępem

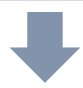

Wyniki obliczenia IA na sekcji sejsmicznej przed i po modyfikacji charakterystyki spektralnej

PRZED

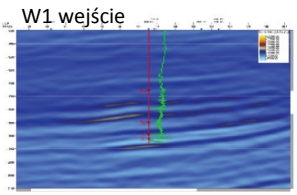

W3 wejście

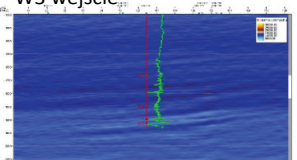

䢰
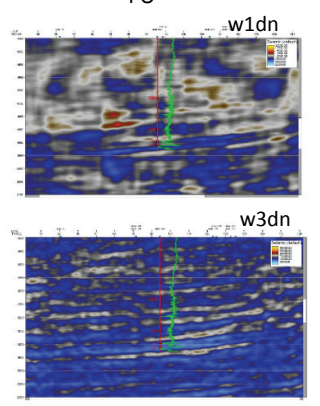

\section{.}

Uwzględnienie wptywu parametrów akwizycji wskazuje, iż zbyt wysoka krotność sumowania skutkuje pojawieniem się zakłóceń niekonsystentnych dla budowy geologicznej

przed modyfikacją widma

po modyfikacji widma składowej

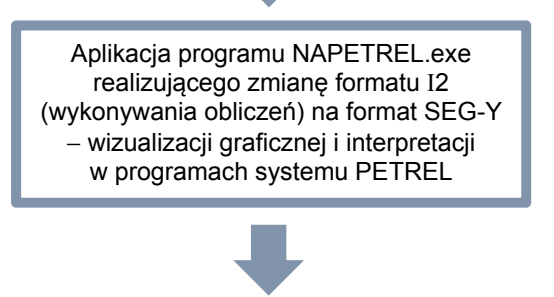

(4)
Rozkład częstotliwości w funkcji czasu podwójnego w zależności od postaci danych poddanych analizie (zastosowanej opcji modyfikacji spektralnej)

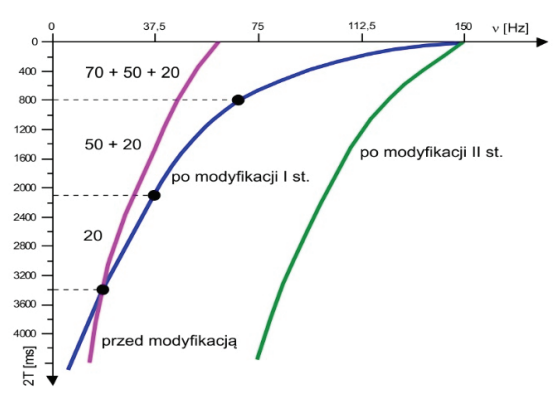

krzywa fioletowa - dane wejściowe: sekcja sumowana, zakres częstotliwości 20-65 Hz

krzywa niebieska - sekcja sumowana po modyfikacji spektralnej I st., zakres częstotliwości $20-150 \mathrm{~Hz}$ krzywa zielona - sekcja sumowana po modyfikacji spektralnej II st., zakres częstotliwości 80-150 Hz

Wyniki zastosowania modyfikacji spektralnej dla pola sprężystego fali podłużnej P (kolumna a) w trzech różnych interwałach czasowych (500-700, 1400-1600, 2200-2300), z wykorzystaniem operatora modyfikacji spektralnej uwzględniającego charakterystykę częstotliwościową fali podłużnej (kolumna c) oraz fali poprzecznej, zapisanych w otworze (składowe: pionowa Z, pozioma radialna SY, pozioma transwersalna SX (kolumny d, e), w porównaniu $\mathrm{z}$ sejsmogramem teoretycznym utworzonym na podstawie krzywych refleksyjności fal P i S, i sygnałów ekstrahowanych $z$ danych polowych o szerokim zakresie częstotliwości (kolumna b)
Uwzględnienie pola sprężystego fali poprzecznej, utworzonego $z$ rejestracji otworowych fal $P$ i S oraz sejsmogramów teoretycznych $z$ danych sejsmiki powierzchniowej
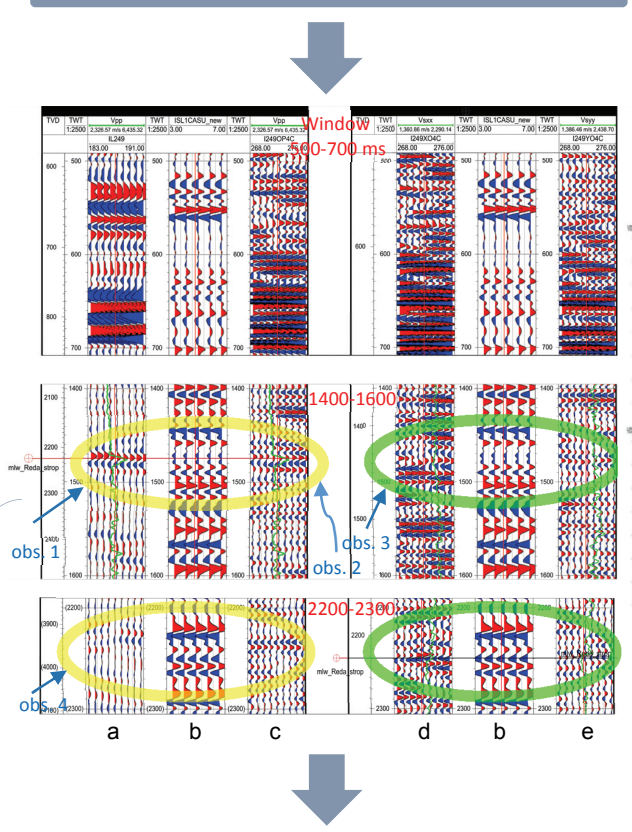

KON IEC
Wyniki zwiększenia rozdzielczości dla danych wejściowych w opcji sekcja sumowana

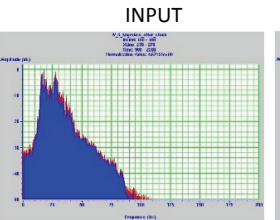

OUTPUT

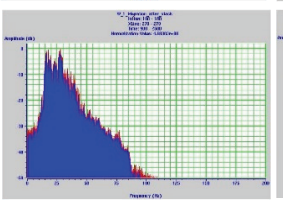
prawy dół: z uwzględnieniem

niskoczęstotliwościowej

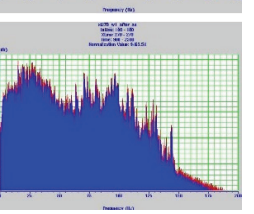

Wyniki modyfikacji spektralnej pola fal podłużnych $(P)$ z wykorzystaniem parametrów fal poprzecznych (S)

do określenia operatora modyfikacji spektralnej

Zestawienie analiz modyfikacji spektralnej wielokomponentowej sekcja sejsmiczna (wiggle) sekcja impedancji (kolor)

Fala S_poziom sylurski_interwał 1600-1950

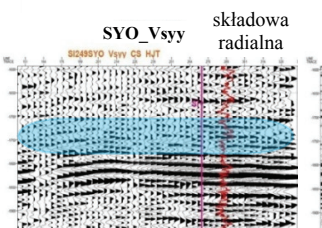

SXO_Vsxx składowa
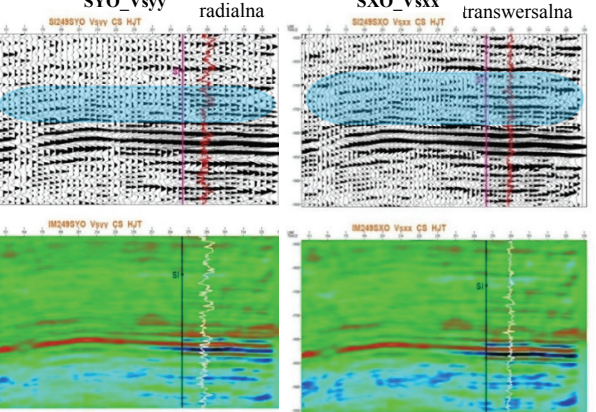

interwał "niebieski” na sekcji sejsmicznej „wiggle”

wyraźnie wskazuje na zróżnicowanie obrazu falowego w

zależności od wykorzystania określonej składowej fali S

Rys. 5. Schemat logiczny i logistyczny rozwiązania zagadnienia zwiększenia rozdzielczości sekcji sejsmicznych 
Z założenia interaktywne podejście (geofizyk-programgeofizyk-program) do określenia operatora modyfikacji spektralnej wymaga szczegółowego zdefiniowania licznego zestawu parametrów wejściowych, zarówno dla danych sejsmicznych (format SEG-Y przekształcony w plik binarny I2 o bezpośrednim dostępie), jak i danych otworowych (plik danych typu LAS).

Bogata literatura anglojęzyczna tego zagadnienia niestety najczęściej opisuje wyniki udanych eksperymentów bez żadnych objaśnień dotyczących założeń metodycznych realizowanych procedur. Informacji o nieudanych eksperymentach niestety nie można znaleźć, a taka właśnie często więcej mówi o nowej metodyce. Jako przykład zacytować można fragment oferty zamieszczonej na stronie www.cgg. com/.../BroadSeis przez jednego z najpotężniejszych właścicieli oprogramowania o uogólnionej nazwie BROAD BANDWIDTH; w swoich materiałach reklamowych pisze:

„Sejsmika szerokopasmowa, którą obejmuje oprogramowanie z serii BroadSeis, umożliwia znaczne polepszenie interpretacji dzięki zwiększeniu zakresu wysokich częstotliwości, odpowiedzialnych za odtworzenie drobnych szczegółów budowy strukturalnej, litologicznej i stratygraficznej. Istotnie ułatwia identyfikację warstw cienkich oraz wyklinowań. Zwiększa wiarygodność dowiązań danych profilowań otworowych, stratygraficznych, wyników analiz laboratoryjnych i danych inżynierii złoża. Natomiast zwiększenie zakresu charakterystyki spektralnej w stronę niskich częstotliwości ułatwia identyfikację obiektów głęboko zalegających, zwiększa też stabilność sejsmicznego pola falowego, co stanowi ważny warunek poprawności inwersji sejsmicznej, zarówno w wersji BEFORE, jak i POST STACK",

Charakterystyczne jest, że wszelkie informacje zawarte w materiałach publikowanych [1-6, 12, 13, 19-22], jak też prezentowanych na stronach internetowych nie zawierają żadnych wskazań odnośnie do podstaw teoretycznych przedstawionych rozwiązań. Tym większa więc waga rodzimych rozwiązań, takich m.in. jak w zadaniu realizowanym w ramach projektu Blue Gas - Polski Gaz Łupkowy.

W przedstawionej koncepcji założono, że odzyskanie szerokiego pasma częstotliwości, właściwego propagacji pola sprężystego czy elastycznego, wyłącznie na podstawie danych sejsmicznych, nie jest możliwe ze względu na efekty wynikające z procesu akwizycji oraz przetwarzania danych, jak też - przede wszystkim - właściwości pochłaniających, absorpcyjnych oraz tłumiących, charakterystycznych dla systemu geologicznego, jakim jest ośrodek geologiczny (Earth system). Założono więc konieczność dodatkowego źródła informacji, o wyższym zakresie rejestrowanych częstotliwości, charakteryzujących ośrodek geologiczny. Źródłem informa- cji dodatkowej, uzupełniającej, w prezentowanym przypadku są dane profilowania akustycznego (PA). W przedstawionym algorytmie i programie uwzględniono możliwość wykorzystania pomiarów profilowania prędkości 3C (fale podłużne i poprzeczne - składowe PZ, SX, SY), co stanowi istotne rozszerzenie w stosunku do rozwiązania wcześniej opatentowanego (w latach 2011-2014).

Istotnym elementem zaproponowanej metodyki jest wnikliwa analiza kolejnych etapów obliczeń i wyodrębnienie takich przedziałów częstotliwości, które charakteryzują dany obiekt geologiczny (target-oriented frequency). Jak pokazano, rozszerzenie pasma częstotliwości i uzyskanie sygnału typu SPIKE nie mogą stanowić wyłącznego kryterium polepszania rozdzielczości zapisu sejsmicznego.

Standardową miarą efektywności polepszenia rozdzielczości sekcji sejsmicznej, poprzez poszerzenie zakresu kompleksowego widma częstotliwościowego, jest możliwość odtworzenia szczegółów budowy o wymiarach mniejszych niż 1/8 $\lambda$ (długości fali) ośrodka geologicznego. Najczęściej wymieniane są tu układy warstw cienkich, wyklinowania, zmienność litofacjalna. Podstawowym, ale też bardzo ogólnym kryterium jest kształt widma amplitudowego. Im szersze widmo, tym bardziej sygnał sejsmiczny kształtem zbliżony jest do szpilki (SPIKE), a więc prawie cała energia skupiona $\mathrm{w}$ czasie początkowym (sygnał zerofazowy). Taka koncepcja utrzymywała się przez wiele lat, stąd operacja dekonwolucji była jedną z podstawowych procedur przetwarzania. Aktualnie coraz częściej zwycięża świadomość, że sygnał zerofazowy jest sygnałem nierzeczywistym, a więc, że pomimo stosowania zabiegów ściągania i rozciągania (squeezing and stretching) sygnału sejsmicznego przyjęcie zerofazowości sekcji może prowadzić w interpretacji do przekłamania szczegółowej budowy geologicznej.

Powyższe wyjaśnienia usprawiedliwiają przytoczenie poniżej szczegółowej instrukcji posługiwania się oprogramowaniem, bowiem intencją autora jest pokazanie jawności i dostępności metodyki i obliczeń.

\section{INSTRUKCJA realizacji sekwencji programowej HRMSTAND przedstawionej na rysunku 5 (modut 2)}

Ustalenie postaci widma przewidywanego (KOD)

Amplituda i faza - opcja wykonania programu $=1$

Amplituda i faza - opcja wykonania programu $=0$

Widmo przewidywane zapisane w pliku typu ASCII o nazwie WIDPRZEW.dat o strukturze:

- pierwsza linia - liczba wartości widma NW (INTEGER)

- kolejne linie dla $\mathrm{i}=1, \mathrm{NW}$

- częstotliwość H (i) (REAL) [Hz], wartość amplitudy A (i) (REAL) i wartość fazy F (i) (REAL). 
Plik typu ASCII o nazwie HRMSTAND.dan z parametrami sterującymi w kolejnych liniach:

1) NAZWA - nazwa pliku wejściowego INPUT z danymi sejsmicznymi, ciąg do 30 znaków

2) N (INTEGER) długość trasy w próbkach

3) KWT (INTEGER) kod przekształcania widma amplitudowego bieżącej trasy

$=1 \mathrm{tak}$

$=0$ nie

4) gdy KWT = 1 wczytujemy WPTR, HTP, HTK, HKT, WKT (REAL), gdzie:

WPTR - wartość, o którą widmo podwyższamy HTP, HTK [Hz] - przedział częstotliwości, w którym powyższą czynność wykonujemy ( $\mathrm{P}$ - początek, $\mathrm{K}$ koniec)

HKT $[\mathrm{Hz}]$ - maksymalna częstotliwość widma amplitudowego

WKT - wartość widma amplitudowego dla częstotliwości > HKT

5) KWO (INTEGER) - kod przekształcania widma amplitudowego krzywej refleksyjności Rc

$=1 \mathrm{tak}$

$=0$ nie

6) gdy KWO = 1 wczytujemy WPRO, HOP, HOK, HKO, WKO (REAL)

WPRO - wartość, o którą widmo podwyższamy
HOP, HOK [Hz] - przedział częstotliwości, w którym powyższą czynność wykonujemy ( $\mathrm{P}$ - początek, $\mathrm{K}$ - koniec) HKO $[\mathrm{Hz}]$ - maksymalna częstotliwość widma amplitudowego

WKO - wartość widma amplitudowego dla częstotliwości > HKO

7) NAZWA - nazwa pliku wyjściowego OUTPUT z modyfikowanymi danymi sejsmicznymi, ciąg do 30 znaków

8) KOD (INTEGER) kod opcji wykonania programu

$=0 \quad$ modyfikacja z zadanym widmem amplitudowym (amplituda - iloraz amplitud widma przewidywanego i bieżącej trasy, faza trasy bieżącej)

$=1$ modyfikacja $\mathrm{z}$ zadanym widmem amplitudowym i fazowym (amplituda - iloczyn amplitud widma przewidywanego i trasy bieżącej, faza - suma faz widma przewidywanego i bieżącej trasy)

9) DT (INTEGER) [ms] - krok próbkowania

10) TP (INTEGER) [ms] - czas początkowy przetworzenia

11) TK (INTEGER) [ms] - czas końcowy przetworzenia $\mathrm{M}=(\mathrm{TK}-\mathrm{TP}) / \mathrm{DT}+1<=2000$ nie może być liczbą pierwsza

12) ILT (INTEGER) - liczba tras do obróbki

13) NR 1 (INTEGER) - numer pierwszej obrabianej trasy Wykonanie programu - wciśnięcie HRMSTAND.exe Wyjście pliku o zadanej nazwie - plik binarny o bezpośrednim dostępie (DIRECT).

Przykład zapisu parametrów wymaganych przez program HRMSTAND oraz ich opis

\begin{tabular}{|c|c|c|c|}
\hline \multirow{12}{*}{ 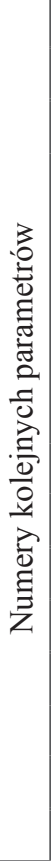 } & (1) & xlwe10285.bin & nazwa pliku z danymi wejściowymi INPUT \\
\hline & (2) & 2001 & $\mathrm{~N}$ - długość trasy w próbkach \\
\hline & (3) & 1 & KWT - kod przetwarzania (podnoszenia) widma trasy bieżącej (każda przetwarzana tak samo) \\
\hline & (4) & $\begin{array}{lll}0.44 & 66.75 & 100 \\
150 . & 0 .\end{array}$ & $\begin{array}{l}\text { WPTR, HTP, HTK, HKT, WKT - parametry określone z trasy najbliższej otworowi (stosowane dla } \\
\left.\text { całej sekcji } T_{\mathrm{BR}}, 1-\mathrm{N}\right) \\
\text { WPTR - wartość dodawana do widma amplitudowego } \\
\text { HTP, HTK - początek i koniec przedziału, w którym dodajemy wartość WPTR [Hz] } \\
\text { HTK } \div \text { HKT - przedział, w którym dokonujemy liniowego zejścia od wartości widma dla HTK do } \\
\text { wartości widma dla HKT } \\
\text { WKT - wartość nadawana dla częstotliwości powyżej HKT }\end{array}$ \\
\hline & $(5)$ & 0 & KWO - kod przetwarzania widma przewidywanego \\
\hline & (6) & sx1028gu.bin & nazwa pliku wyjściowego OUTPUT po modyfikacji spektralnej \\
\hline & (7) & 1 & kod egzekucji programu \\
\hline & (8) & 2 & krok próbkowania $[\mathrm{ms}]$ \\
\hline & $(9)$ & 0 & $\mathrm{TP}$ - czas początkowy obróbki trasy [ms] \\
\hline & $(10)$ & 3998 & TK - czas końcowy obróbki trasy [ms] \\
\hline & $(11)$ & 944 & ILT - liczba tras do obróbki \\
\hline & $(12)$ & 1 & NR 1 - numer pierwszej obrabianej trasy w pliku \\
\hline
\end{tabular}

$\mathrm{WTC}=$ tylko wykorzystuje sekcje 


\section{Modyfikacja spektralna sejsmicznego pola sprężystego w obliczu wyzwań i wymagań prospekcji i eksploatacji niekonwencjonalnych złóż węglowodorów}

Jak wspomniano we wstępie, celem prezentowanego w niniejszej publikacji problemu jest rozwiązanie zadania zwiększenia rozdzielczości sekcji sejsmicznej, często rozumianej tożsamo - co nie do końca jest poprawne - jako poszerzenie zakresu częstotliwościowego pola falowego rejestrowanego metodą sejsmiczną.

Najważniejszy parametr ośrodka geologicznego odzyskiwany z udziałem metody sejsmicznej to prędkość propagacji fal sprężystych, najczęściej tzw. podłużnych (P - primary) objętościowych, ale też fal poprzecznych ( $\mathrm{S}$ - secondary) skręceniowych. Prędkość propagacji fal oraz częstotliwość, jak już wspomniano, związane są zależnością „dyspersyjną".

Identycznie ten sam ośrodek fizyczny (geologiczny) może być opisany różnymi wartościami prędkości propagacji fali sprężystej - w zależności od tego, w jakim paśmie częstotliwości prowadzony jest pomiar tego parametru, w laboratorium lub podczas rejestracji polowej sejsmiki powierzchniowej i otworowej (projekty sejsmiki 2D i 3D fal podłużnych lub wielokomponentowych, jak też w ramach pionowego profilowania sejsmicznego PPS (ang. VSP) oraz profilowania akustycznego PA w otworze). Implikacje tego faktu są niezwykle rozległe dla poprawności interpretacji geofizyczno-geologicznej danych sejsmicznych - zarówno pozytywne, ułatwiające i przyśpieszające poprawne rozwiązanie zadania, jak też niekiedy negatywne, wprowadzające wieloznaczność rozumienia uzyskanych wyników.

Ponieważ prędkość propagacji fal sprężystych jest związana z ogromną większością parametrów fizycznych, petrofizycznych, geomechanicznych, a nawet geochemicznych

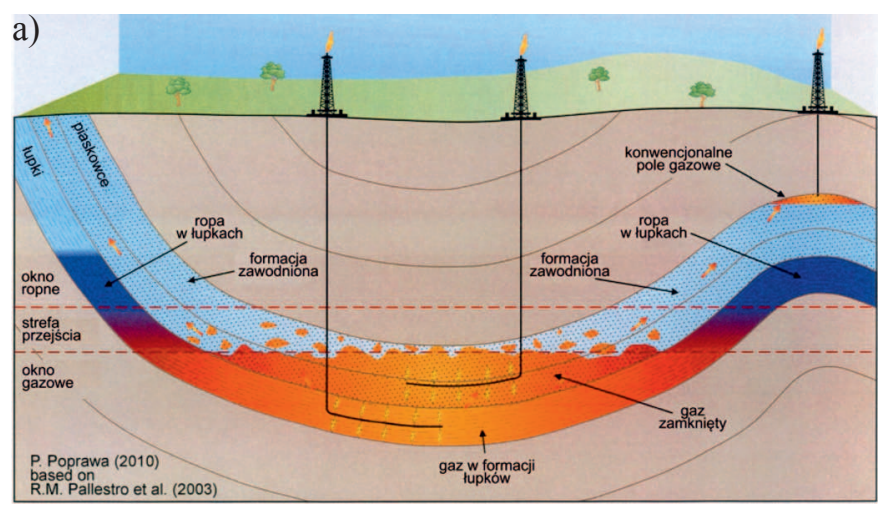

Rys. 6. Konwencjonalne i niekonwencjonalne obiekty złożowe (a) oraz schemat akwizycji dla projektu sejsmicznego (b) (według P. Poprawa, 2010, zmienione; według H. Jędrzejowska-Tyczkowska, 2014, zmienione) ośrodka, poprawność odtworzenia pola prędkości fal sejsmicznych ma fundamentalne znaczenie we wszelkich pracach związanych zarówno z eksploracją, udostępnianiem, jak i eksploatacją oraz monitoringiem złóż ropy i gazu. Dotyczy to szczególnie tzw. złóż niekonwencjonalnych - ze względu na ich nietypową geometrię budowy geologicznej oraz znaczną niejednorodność budowy litologiczno-facjalnej.

Samo zwiększenie rozdzielczości, czy poszerzenie zakresu częstotliwości, nie jest zadaniem szczególnie trudnym dla sejsmika rozumiejącego teorię propagacji fal sprężystych. Służą do tego między innymi techniki filtracji, dekonwolucji, modelowanie sejsmogramów teoretycznych itd. Natomiast ,utrafienie” w założony cel geologiczny, ukryty na głębokości kilku kilometrów pod powierzchnią ziemi, to znacznie trudniejsze zadanie, zarówno ze względu na nieznane rozmiary obiektów, jak i nieznane wartości parametrów fizycznych.

Mając powyższe na uwadze, w komentowanym rozwiązaniu dokonano uszczegółowienia sformułowania celu realizacji, poprzez wprowadzenie określenia ,zwiększenie rozdzielczości sekcji sejsmicznej ukierunkowanej na wskazany cel geologiczny".

$\mathrm{W}$ prezentowanym rozwiązaniu podstawowy potencjał studyjny położono na znalezieniu dodatkowego źródła informacji, które w teoretycznie i praktycznie poprawny i zasadny sposób umożliwiłoby odzyskanie takich częstotliwości pola falowego, które ze względu na charakterystykę fizyczną badanego obiektu powinny być zarejestrowane, jednakże zostały „wyeliminowane” na skutek braku perfekcyjności zarówno w metodyce, jak i w polowej realizacji technicznej.

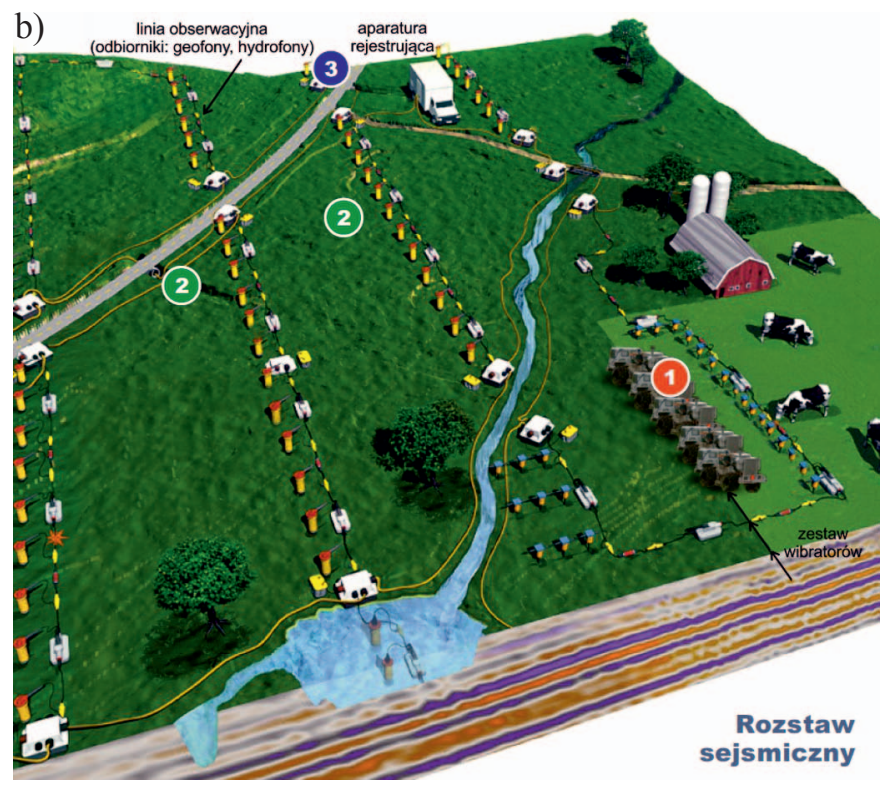


Za takie dodatkowe źródło informacji uznane zostało profilowanie akustyczne PA (pomiar 1D o dużej rozdzielczości pionowej i szerokiej charakterystyce częstotliwości źródła $f_{\text {sejsmiki }}<<f_{\mathrm{PA}}$ ), które zawsze traktowane jest jako wsparcie interpretacji danych sejsmicznych (między innymi konstrukcje sejsmogramów teoretycznych).
Proponowane nowatorskie podejście polega na konstrukcji, poprzez porównawczą analizę charakterystyki spektralnej PA i danych sejsmicznych, stosownego operatora modyfikacji spektralnej sejsmicznego pola falowego, i w konsekwencji na wyborze potrzebnego i pożądanego dla danego obiektu geologicznego zakresu częstotliwości.

\section{Wstępne analizy efektywności modyfikacji spektralnej pola sejsmicznego}

Wstępne analizy efektywności modyfikacji spektralnej pola sejsmicznego prowadzono na danych sejsmicznych projektu 2D z koncesji W (rejon rowu lubelskiego). Schemat profili sejsmicznych oraz lokalizację otworów S-OU1, B-IG1 i S-OU1 wraz z podziałem stratygraficznym w otworze S-OU1 pokazano na rysunkach 7 i 8 , jak też w tablicy 2 .

Na przedstawionych profilach ciągłe refleksy widzimy jedynie dla utworów jury i kredy (około $0 \div 0,5$ sekundy TWT) oraz dla utworów karbonu (około $0,5 \div 1,2$ sekundy TWT), oraz już znacznie słabsze dla utworów ediakaru, kambru i ordowiku (około 1,7 $\div 2,4$ sekundy TWT, NE część profilu). Utwory syluru i dewonu dolnego charakteryzują się obrazem sejsmicznym praktycznie nieinterpretowalnym. Dodatkowo duże utrudnienie dla właściwego dowiązania geologicznego stanowi brak poprawnej kalibracji otworowej.

Obliczona $\mathrm{z}$ danych profilowania akustycznego krzywa refleksyjności (współczynników odbicia - trasa K, rysunek 8a) wskazuje na brak zróżnicowania oporu akustycznego, począwszy od stropu utworów sylurskich $(\mathrm{H} \cong 1815 \mathrm{~m}, 2 \mathrm{~T} \cong 950 \mathrm{~ms})$.

W konsekwencji należy oczekiwać braku zróżnicowania dynamiki amplitudowej refleksów horyzontów sejsmicznych w powyższym interwale, co potwierdzają różnice w obrazie zarejestrowanego pola sejsmicznego na wybranych do analiz

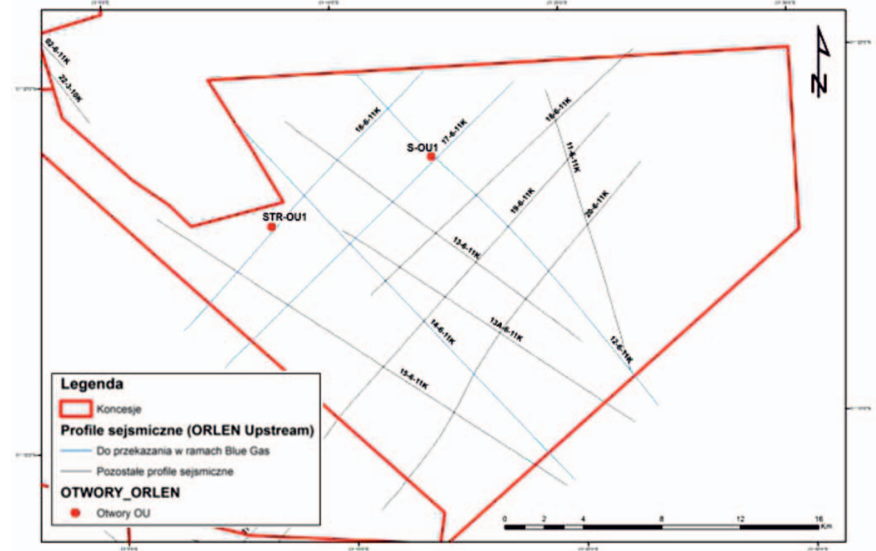

Rys. 7. Schemat zrealizowanych profili

profilach (rysunek 9, lewa kolumna). Sekcje sejsmiczne po modyfikacji (prawa kolumna) cechują się znacznie wyższą częstotliwością obrazu falowego i - szczególnie profile 17-06-11K i 16-06-11K - nieco lepszą czytelnością dla interpretacji.

Porównanie pola poddanego modyfikacji spektralnej i pola wejściowego potwierdza możliwość zwiększenia czytelności obrazu sejsmicznego. Na podstawie powyższych obserwacji zadecydowano o zastosowaniu procedury modyfikacji spektralnej oraz zwiększenia głębokości penetracji fali sprę-

Tablica 2. Stratygrafia dla otworu S-OU1

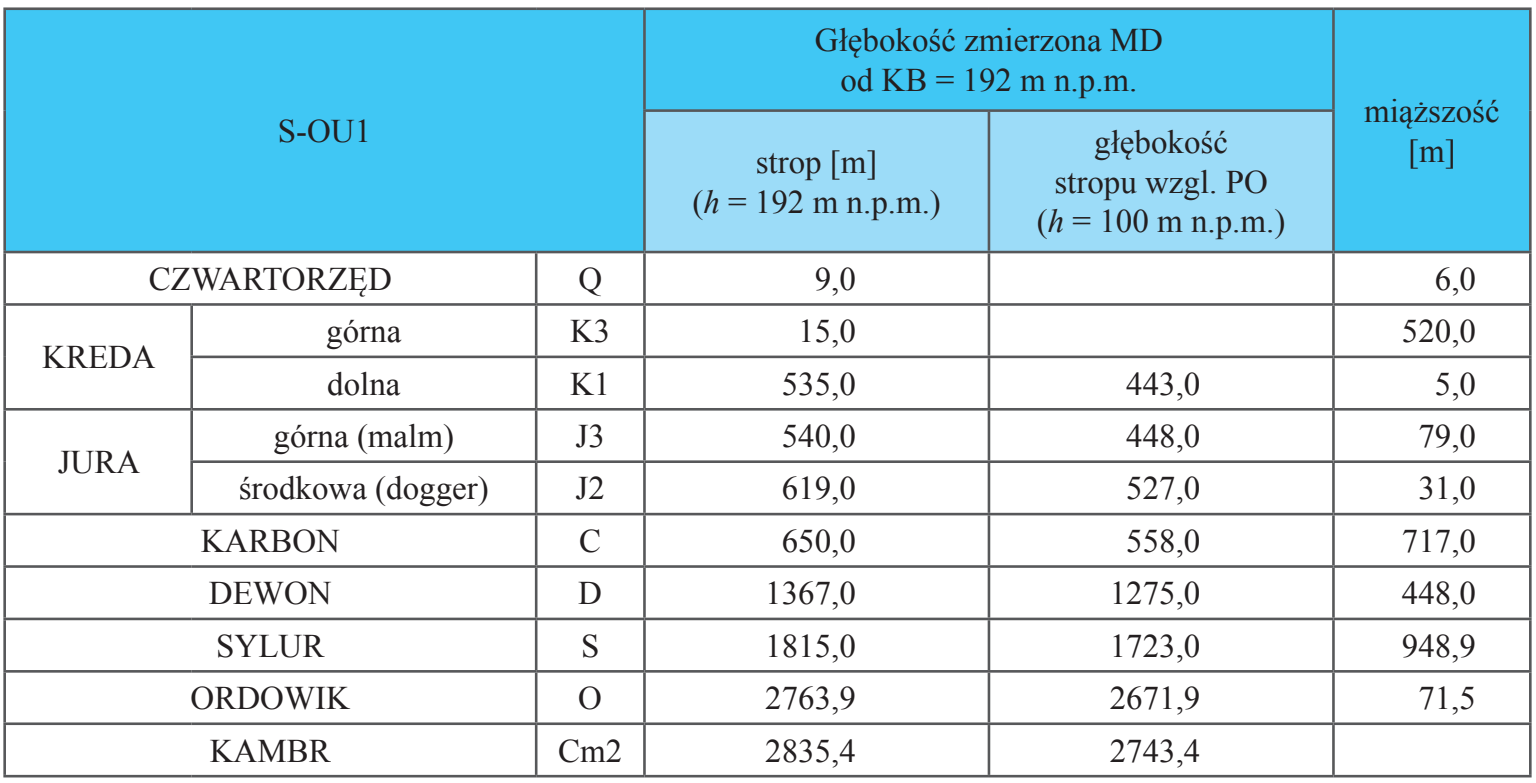



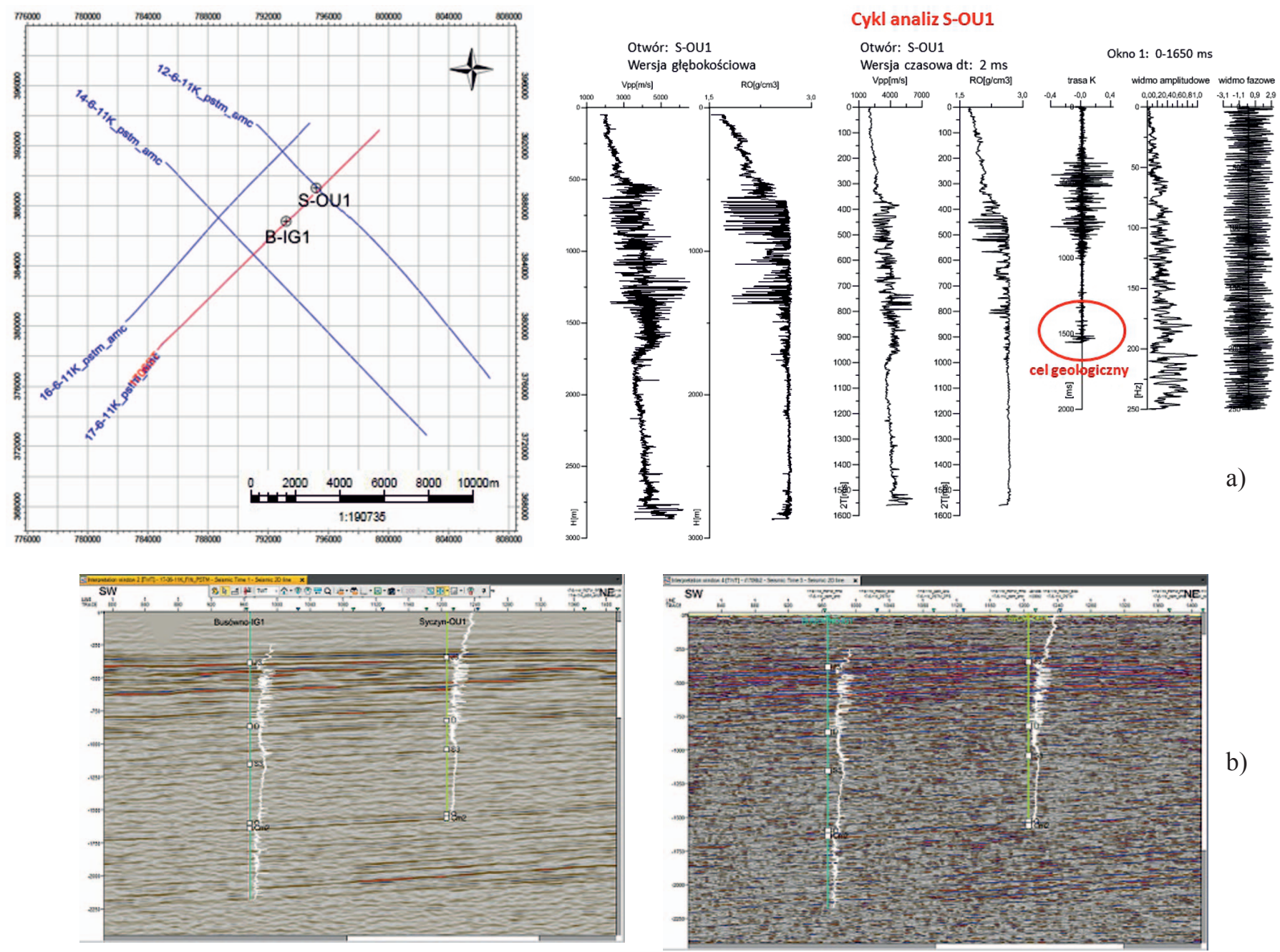

b)

Rys. 8. Dane profilowania akustycznego w otworze S-OU1 w domenie głębokości (a) oraz fragment profilu 17-06-11K z wprowadzonymi danymi profilowania PA otworów S-OU1 i B-IG1 i podstawowymi markerami stratygraficznymi (b)

żystej, według schematów pokazanych na rysunku $5 \mathrm{i}$ uproszczonego na rysunku 10 .

Uzyskanie czytelniejszych materiałów sejsmicznych, o szerszym przedziale częstotliwości, a więc o większej rozdzielczości interpretacji geologicznej, wynikające z zastosowania procedur modyfikacji spektralnej, przeanalizowane zostało na rysunku 11 - dla fragmentu sekcji sejsmicznej w pobliżu otworu S-OU1 oraz na rysunku 12 - dla fragmentu sekcji sejsmicznej w pobliżu otworu B-IG1 - w rejonie rowu lubelskiego.

Ze względu na dość niską jakość zarówno danych sejsmicznych, jak i otworowych, szczególnie dla odwiertu B-IG1, wykorzystano koncepcję sejsmogramów teoretycznych, utworzonych z krzywej rozkładu współczynników odbicia (tablica 3), której splot z różnymi sygnałami pozwala a priori oszacować przedział i zakres częstotliwości potrzebnych do uzyskania rozdzielczości zbliżonej do rozdzielczości danych otworowych (rysunek 13).

Aplikując sygnał elementarny o częstotliwości $30 \mathrm{~Hz}$, uzyskujemy widmo amplitudowe nieprzekraczające $\sim 47 \mathrm{~Hz}$ czę- stotliwości efektywnej. Podniesienie częstotliwości dominującej sygnału do wartości $60 \mathrm{~Hz}$ (rysunek 12) zwiększa zakres częstotliwości efektywnych (użytecznych) widma amplitudowego do wartości około $115 \mathrm{~Hz}$, czyli o przeszło 4 oktawy w stosunku do sekcji sejsmicznej wejściowej. Zwiększenie zakresu częstotliwościowego widma skutkuje wzrostem pionowej rozdzielczości czasowej sekcji sejsmicznej z wartości $30 \div 90 \mathrm{~ms}$ do wartości $10 \div 15 \mathrm{~ms}$ dla częstotliwości sygnału $30 \mathrm{~Hz}$ i $60 \mathrm{~Hz}$, kolejno dla otworów S-OU1 i B-IG1.

Sekwencję obliczenia operatora modyfikacji spektralnej przedstawiono na rysunku 14 . Wykorzystano moduł programowy HRMSTAND - realizujący między innymi formuły $10 \div 15$ analizy Fouriera.

Pozytywny efekt zabiegów widać na rysunku 15. Profil 17-06-11K po modyfikacji spektralnej może już być poddany interpretacji, ale poprawność wyniku będzie można ocenić dopiero po odwierceniu kolejnych odwiertów.

Jednym z najbardziej spektakularnych efektów modyfikacji spektralnej jest zróżnicowanie pola prędkości odtworzonego za pomocą inwersji sejsmicznej (rysunek 16). Wpro- 
Tablica 3. Wybrane, przeliczone do skali czasu wyniki profilowania akustycznego w otworach S-OU1 i B-IG1

\begin{tabular}{|c|c|c|c|}
\hline \multicolumn{5}{|c|}{ S-OU1 } \\
\hline$T[\mathrm{~ms}]$ & $V[\mathrm{~m} / \mathrm{s}]$ & $\mathrm{RO}$ & $\mathrm{K}$ \\
\hline 930,000 & 4016,242 & 2,687 & $-0,02397$ \\
\hline 950,000 & 4574,963 & 2,592 & 0,03468 \\
\hline 970,000 & 4132,681 & 2,642 & $-0,02269$ \\
\hline 990,000 & 3690,339 & 2,651 & 0,03786 \\
\hline 1010,000 & 3429,561 & 2,646 & 0,01090 \\
\hline 1030,000 & 3957,221 & 2,619 & $-0,00818$ \\
\hline 1050,000 & 3629,690 & 2,639 & $-0,00443$ \\
\hline 1070,000 & 3625,805 & 2,646 & $-0,00598$ \\
\hline 1090,000 & 3772,560 & 2,644 & $-0,00118$ \\
\hline 1110,000 & 3658,007 & 2,649 & $-0,00285$ \\
\hline 1130,000 & 3552,274 & 2,677 & 0,01192 \\
\hline 1150,000 & 3847,811 & 2,650 & 0,00033 \\
\hline 1170,000 & 3760,459 & 2,670 & $-0,00314$ \\
\hline 1190,000 & 3889,549 & 2,663 & $-0,00860$ \\
\hline 1210,000 & 3964,426 & 2,642 & $-0,00425$ \\
\hline 1230,000 & 3893,773 & 2,674 & $-0,00304$ \\
\hline 1250,000 & 4005,587 & 2,663 & 0,00526 \\
\hline 1270,000 & 3961,851 & 2,670 & $-0,00038$ \\
\hline 1290,000 & 4089,976 & 2,661 & 0,03995 \\
\hline 1310,000 & 4080,122 & 2,675 & 0,01385 \\
\hline 1330,000 & 4073,034 & 2,682 & 0,02820 \\
\hline 1350,000 & 3937,284 & 2,689 & 0,01993 \\
\hline 1370,000 & 4112,604 & 2,677 & $-0,01319$ \\
\hline 1390,000 & 4218,770 & 2,683 & $-0,01294$ \\
\hline 1410,000 & 4115,938 & 2,695 & $-0,01066$ \\
\hline 1430,000 & 4265,713 & 2,672 & $-0,01338$ \\
\hline 1450,000 & 4351,896 & 2,667 & $-0,00805$ \\
\hline
\end{tabular}

\begin{tabular}{|c|c|c|c|}
\hline \multicolumn{5}{|c|}{ B-IG } \\
\hline$T[\mathrm{~ms}]$ & $V[\mathrm{~m} / \mathrm{s}]$ & $\mathrm{RO}$ & $\mathrm{K}$ \\
\hline 1180,000 & 3073,991 & 2,622 & 0,03470 \\
\hline 1200,000 & 3306,659 & 2,649 & 0,00547 \\
\hline 1220,000 & 3492,596 & 2,663 & $-0,00125$ \\
\hline 1240,000 & 3604,773 & 2,670 & 0,00644 \\
\hline 1260,000 & 3485,778 & 2,627 & 0,02582 \\
\hline 1280,000 & 3678,499 & 2,656 & $-0,00254$ \\
\hline 1300,000 & 3606,203 & 2,655 & $-0,01316$ \\
\hline 1320,000 & 3689,084 & 2,620 & $-0,01640$ \\
\hline 1340,000 & 3693,444 & 2,648 & $-0,00083$ \\
\hline 1360,000 & 3889,083 & 2,672 & 0,00048 \\
\hline 1380,000 & 3829,217 & 2,681 & 0,01065 \\
\hline 1400,000 & 3660,054 & 2,659 & 0,00989 \\
\hline 1420,000 & 4034,047 & 2,663 & $-0,00977$ \\
\hline 1440,000 & 3767,046 & 2,684 & $-0,00174$ \\
\hline 1460,000 & 3829,950 & 2,695 & 0,00460 \\
\hline 1480,000 & 3835,238 & 2,685 & 0,00952 \\
\hline 1500,000 & 3641,660 & 2,664 & 0,02791 \\
\hline 1520,000 & 3941,850 & 2,681 & $-0,01817$ \\
\hline 1540,000 & 3532,820 & 2,650 & 0,07680 \\
\hline 1560,000 & 4250,978 & 2,683 & $-0,02286$ \\
\hline 1580,000 & 4091,151 & 2,693 & $-0,02259$ \\
\hline
\end{tabular}

wadzone markery stratygraficzne (strefa a1, a2) wykazują lepszą koincydencję w przypadku pola sejsmicznego o szerszym zakresie częstotliwości (strefa b1, b2).

Efekt procedury modyfikacji spektralnej najwyraźniej przedstawia się w ujęciu przestrzennym (3D) - rysunki 17 i 18.

Znacznie bardziej jednoznaczne potwierdzenie efektywności zaproponowanej metodyki wynika z obliczeń i analiz wykonanych przez autora w ramach współpracy z Colorado School of Mines (rysunek 19). Predykcja parametrów zbiornikowych wykonana przez M.L. Wileya (2009) i potwierdzona przez wyniki badań inżynierii złożowej udokumentowana została również przez wartości impedancji akustycznej, a przede wszystkim przez znacznie wyższą rozdzielczość powierzchniową uzyskanej mapy [23]. 
Profil 17-06-11K
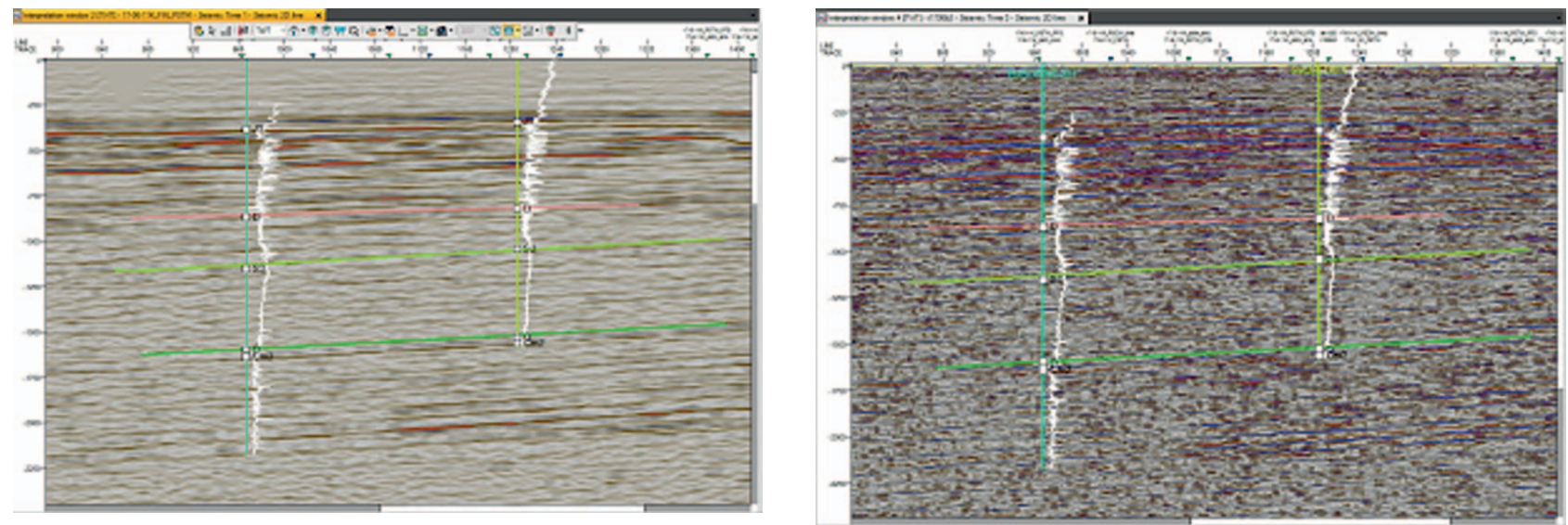

Profil 16-06-11K
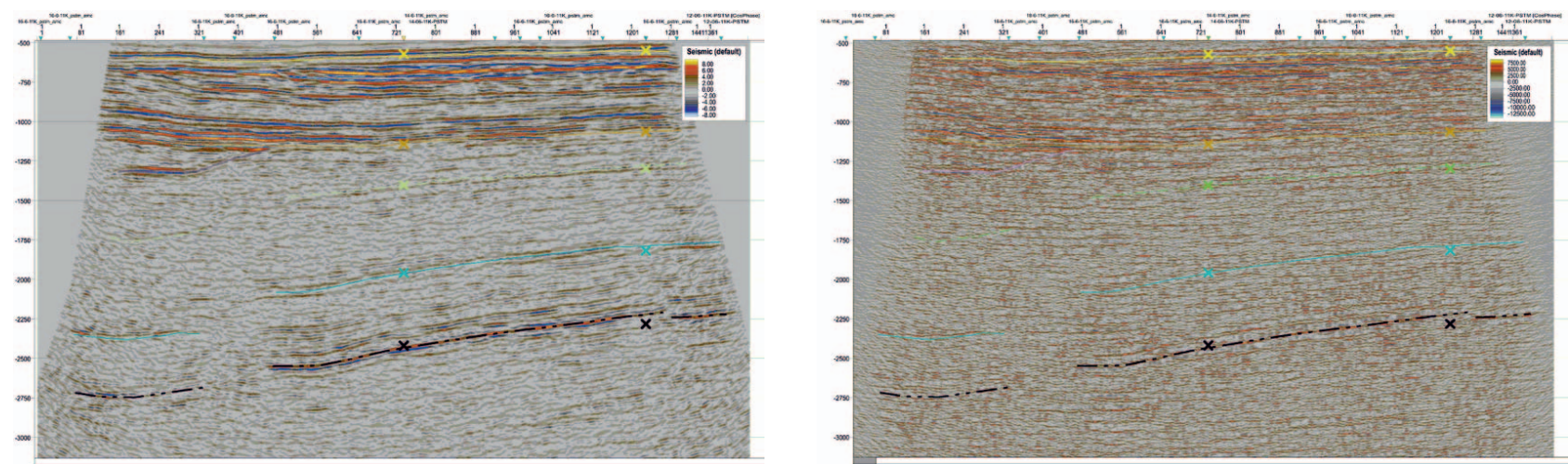

Profil 14-06-11K
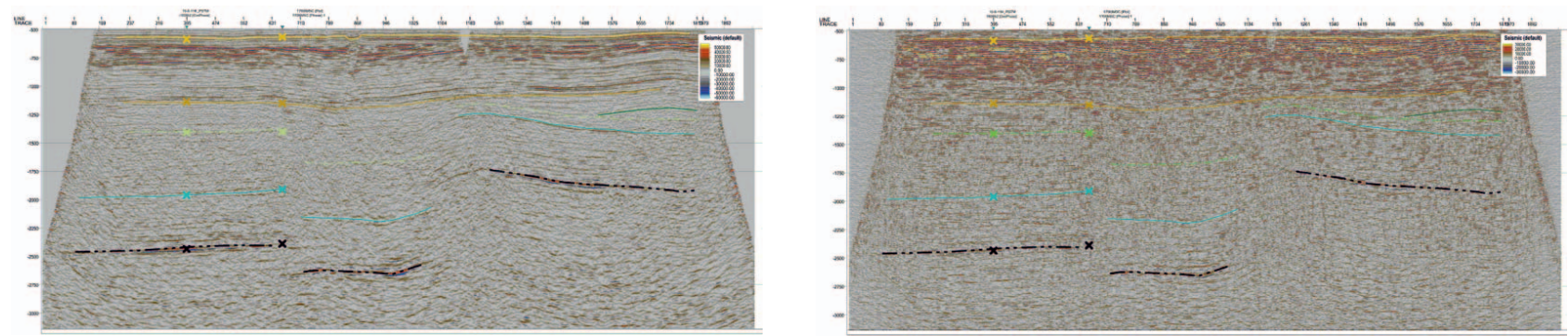

Profil 12-06-11K
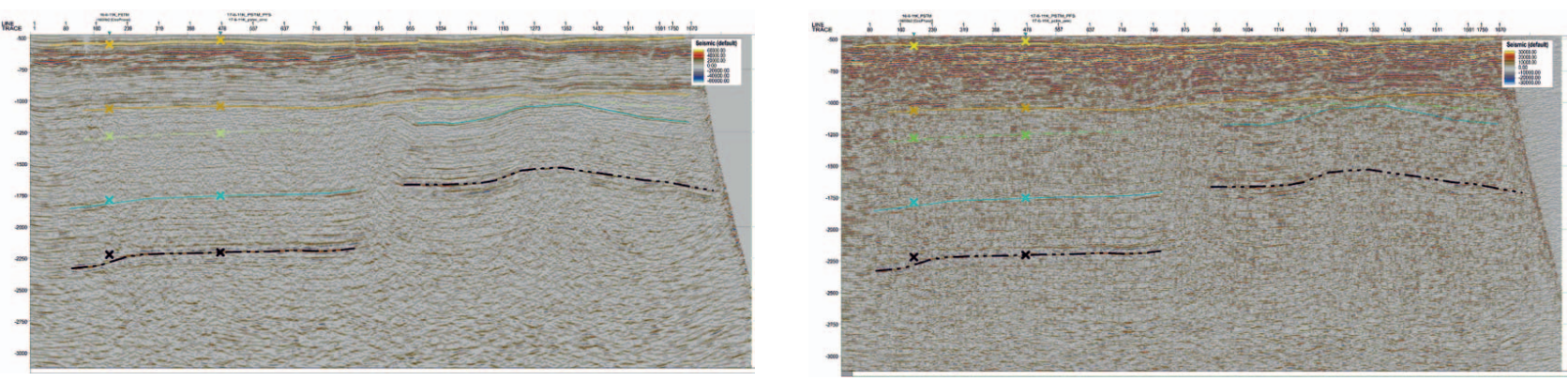

Rys. 9. Prezentacja wybranych do analiz profili sejsmicznych w wersji „dane wejściowe” - prawa kolumna - oraz po modyfikacji spektralnej - lewa kolumna 
ZAŁOŻENIE PROJEKTU

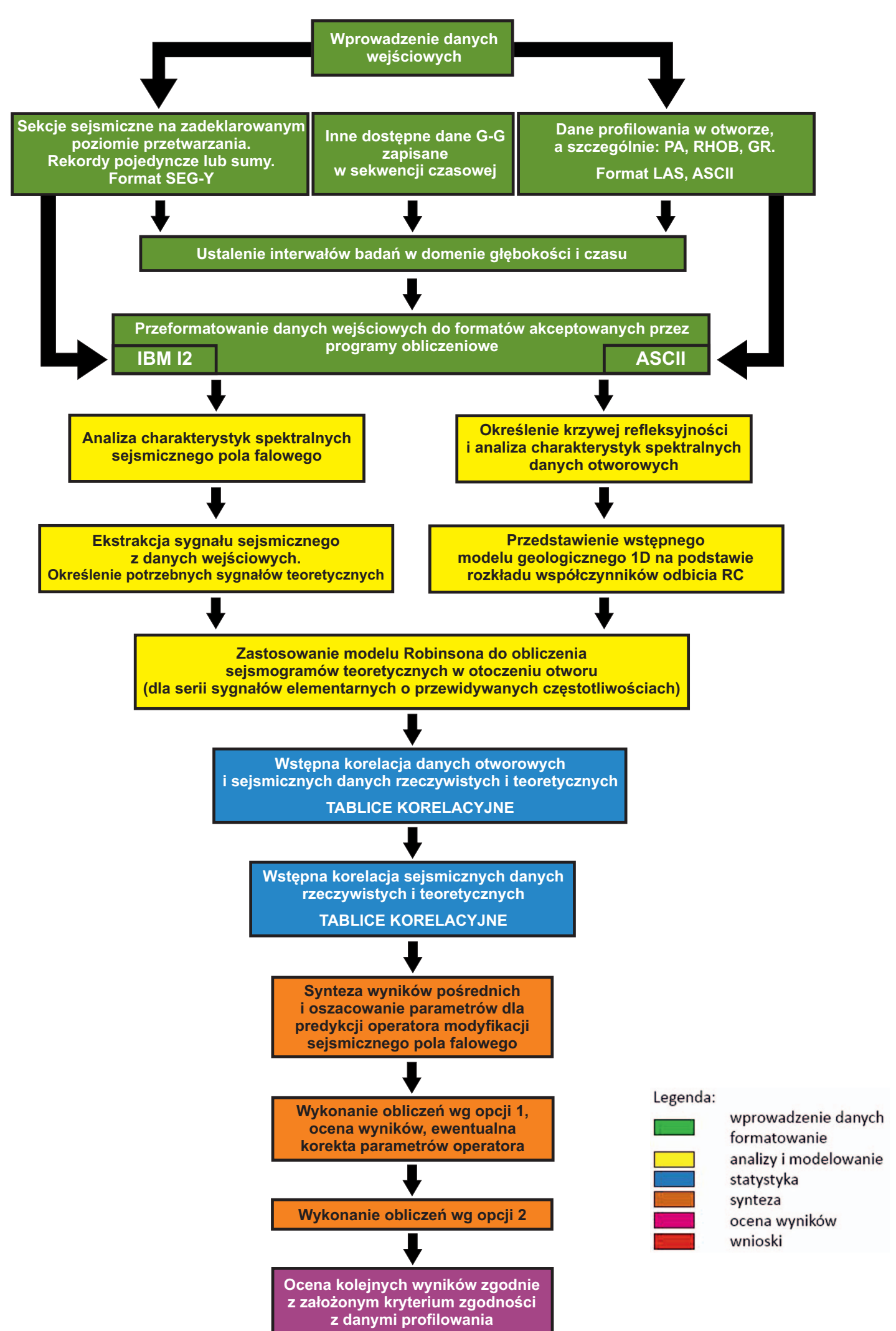

Rys. 10. Schemat ideowy zastosowania oprogramowania w procedurach modyfikacji zespolonej charakterystyki spektralnej sejsmicznego pola falowego 


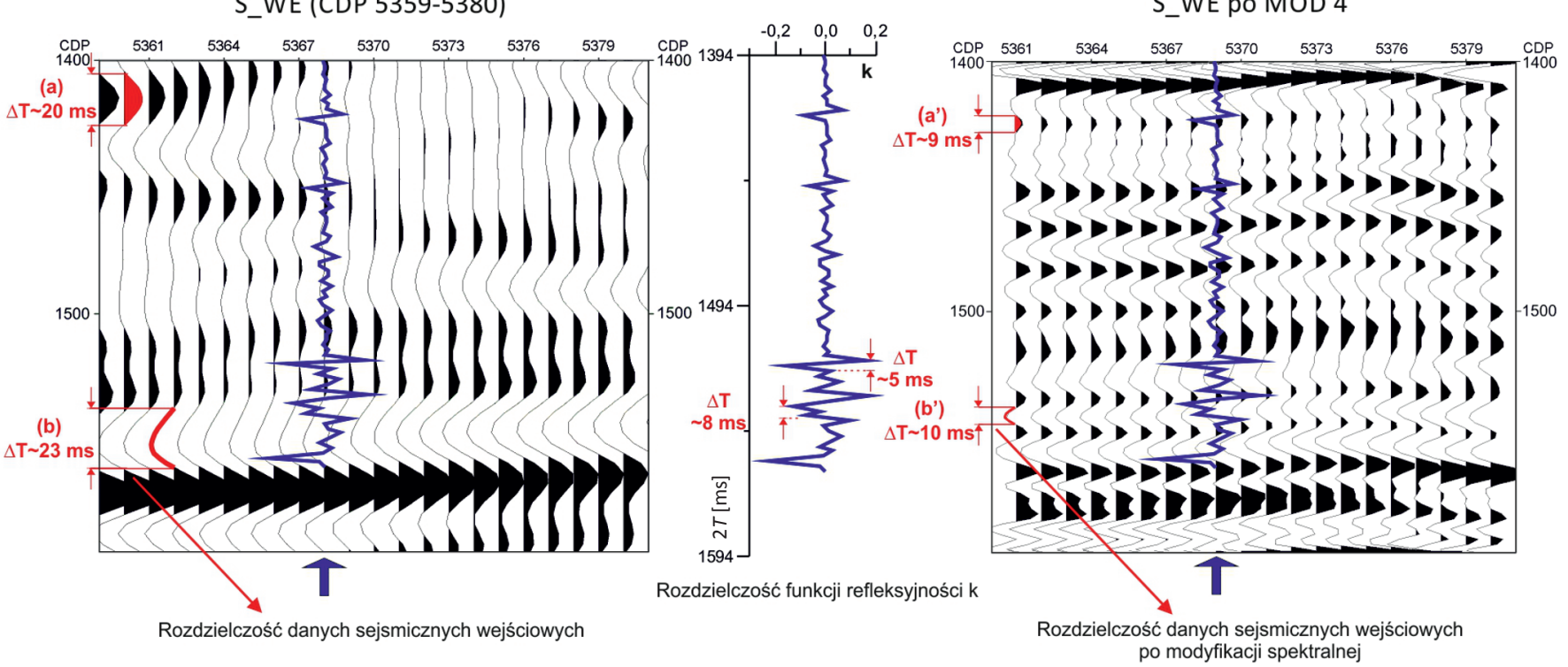

Rys. 11. Profil 17-06-11K. Koncesja W. Otwór S-OU1. Porównanie obrazu falowego wejściowego oraz po jednej z wersji modyfikacji charakterystyki spektralnej

(a)

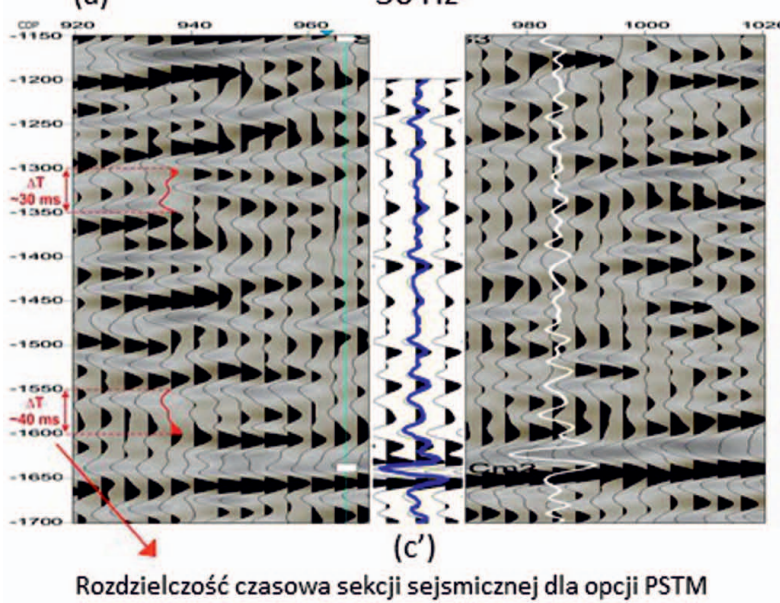

Rozdzielczość czasowa sekcji sejsmicznej dla opcji PSTM
$60 \mathrm{~Hz}$ (b)

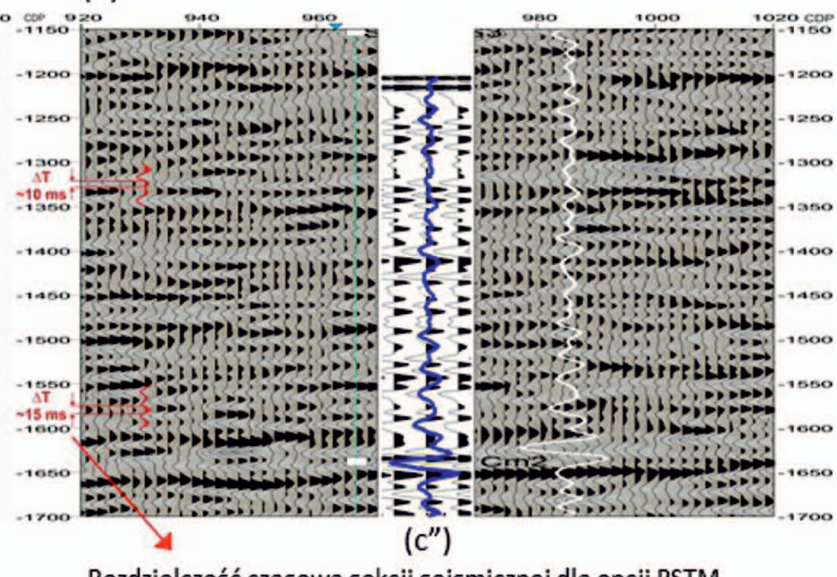

Rozdzielczość czasowa sekcji sejsmicznej dla opcji PSTM po modyfikacji spektralnej

(b)
$60 \mathrm{~Hz}$
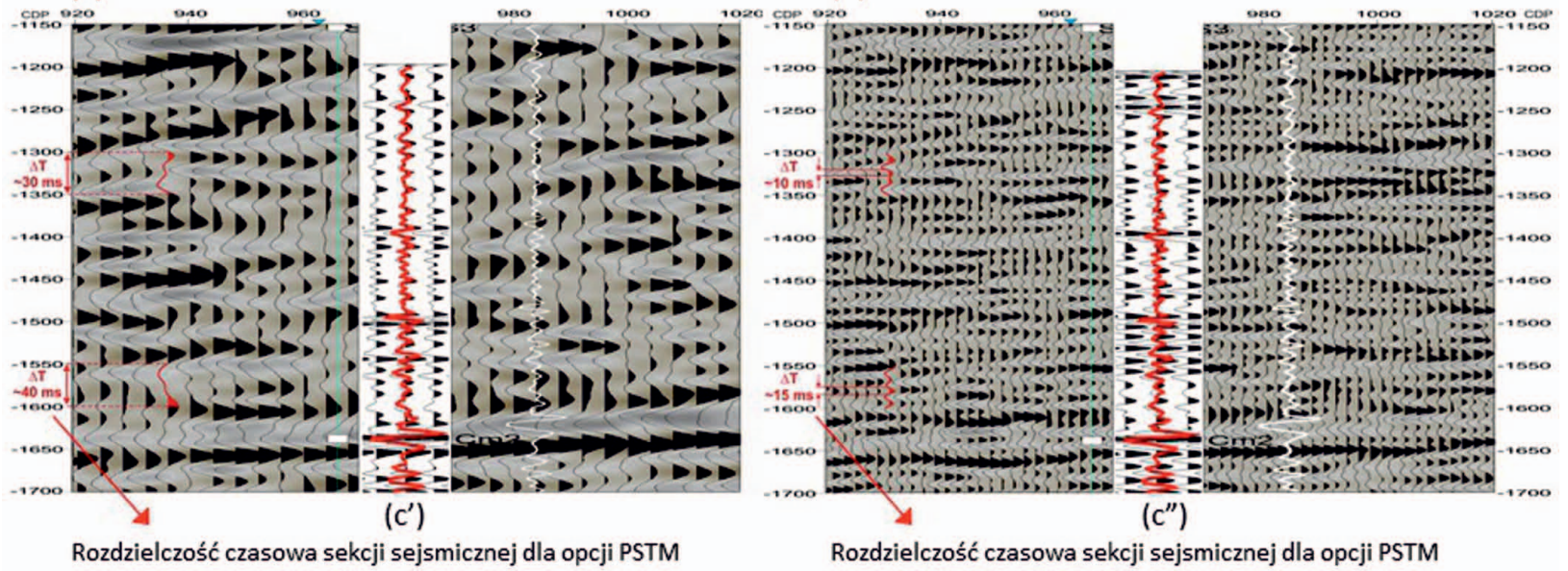

Rozdzielczość czasowa sekcji sejsmicznej dla opcji PSTM po modyfikacji spektralnej

Rys. 12. Profil 17-06-11K. Koncesja W. Otwór B-IG1. Porównanie sekcji sejsmicznych opcji PSTM (a) oraz po zastosowaniu modyfikacji spektralnej (b) odniesionych do sejsmogramów teoretycznych przed (c') i po (c") modyfikacji spektralnej, obliczonych na podstawie krzywej refleksyjności i sygnału elementarnego $30 \mathrm{~Hz}$ i $60 \mathrm{~Hz}$ w interwale $1200 \div 1700 \mathrm{~ms}$ 
Pole sejsmiczne wejściowe PSTM

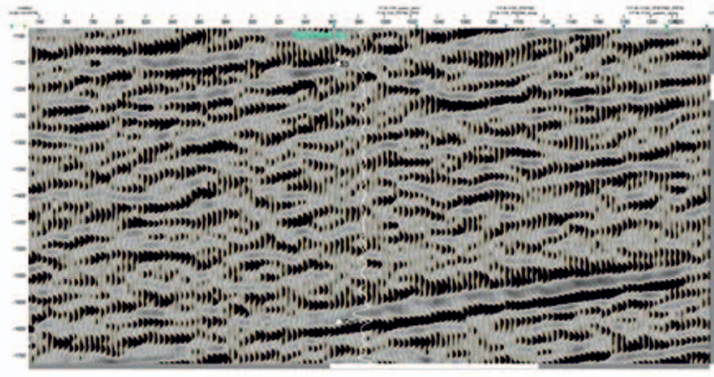

Pole sejsmiczne po modyfikacji spektralnej

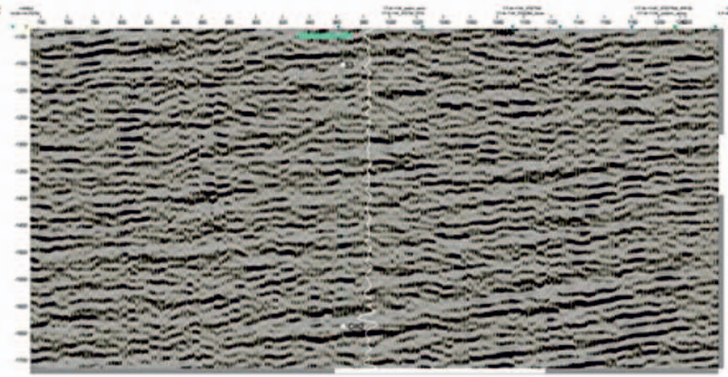

Rys. 13. Wyniki podwyższenia rozdzielczości sekcji sejsmicznej na przykładzie profilu 17-06-11K. Koncesja W. Otwór B-IG1

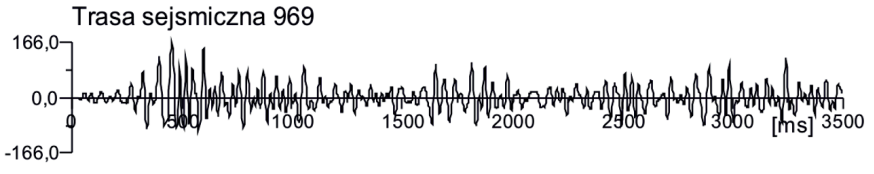

$$
\text { Widmo amplitudowe }
$$
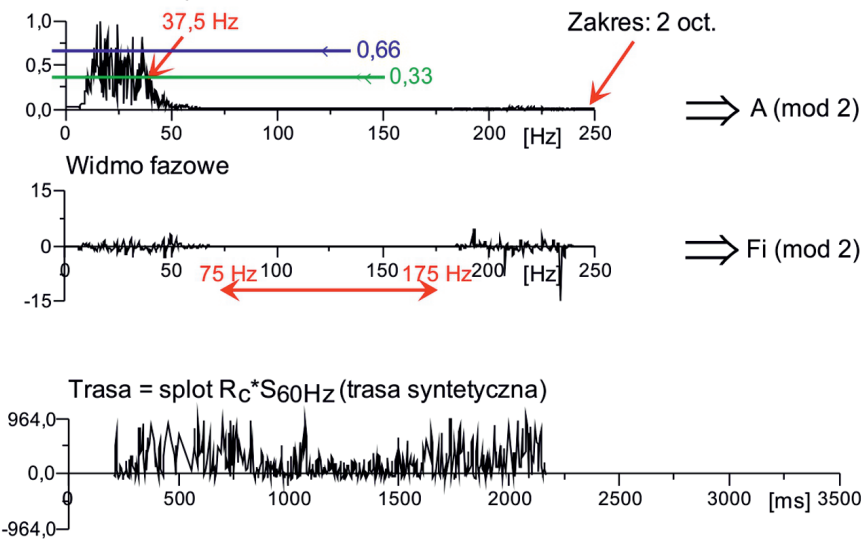

$-964,0$
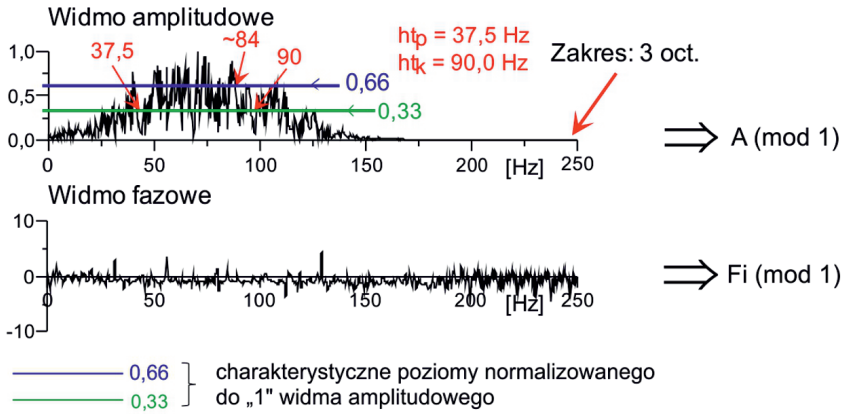

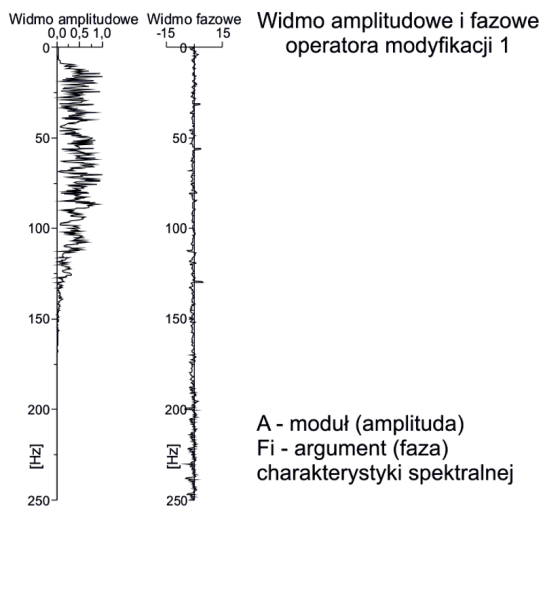

Rys. 14. Sekwencja obliczenia operatora modyfikacji spektralnej (według programu HRMSTAND, rysunek 5)

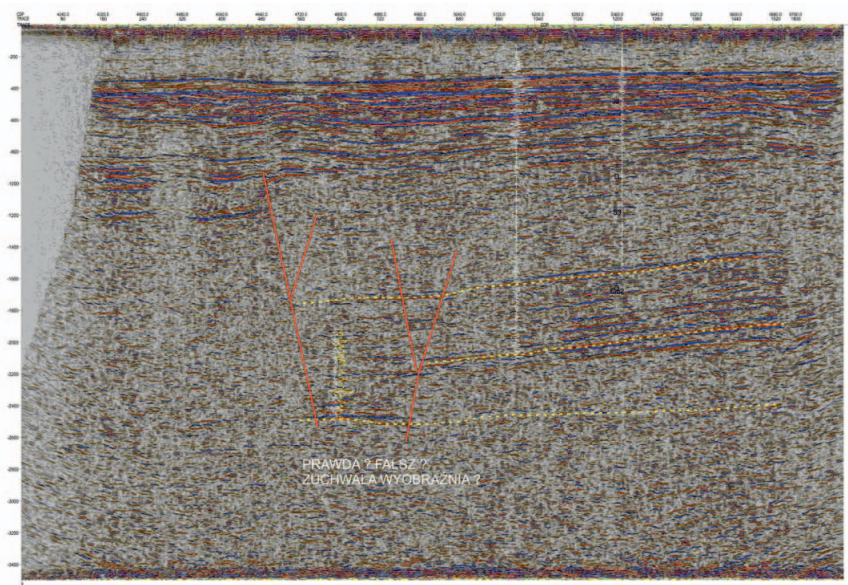

Rys. 15. Profil 17-06-11K. Próba interpretacji. Szukanie analogii w dwóch różnych strefach przyuskokowych 

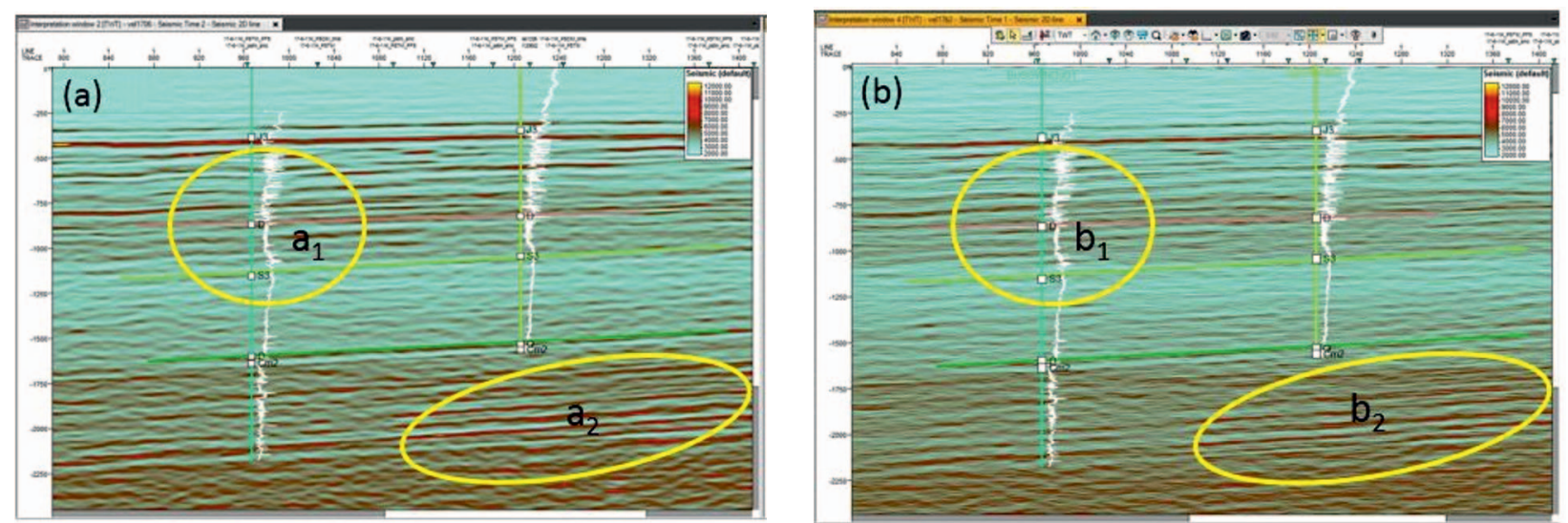

Rys. 16. Wyniki inwersji sejsmicznej w postaci pola prędkości po (a) i przed (b) zastosowaniem procedury modyfikacji spektralnej. Obserwowane na polu prędkości inwersyjnych zróżnicowanie obrazu potwierdza skuteczność modyfikacji spektralnej

\section{vel: $3560 \div 4500 \mathrm{~m} / \mathrm{s}$}

a)

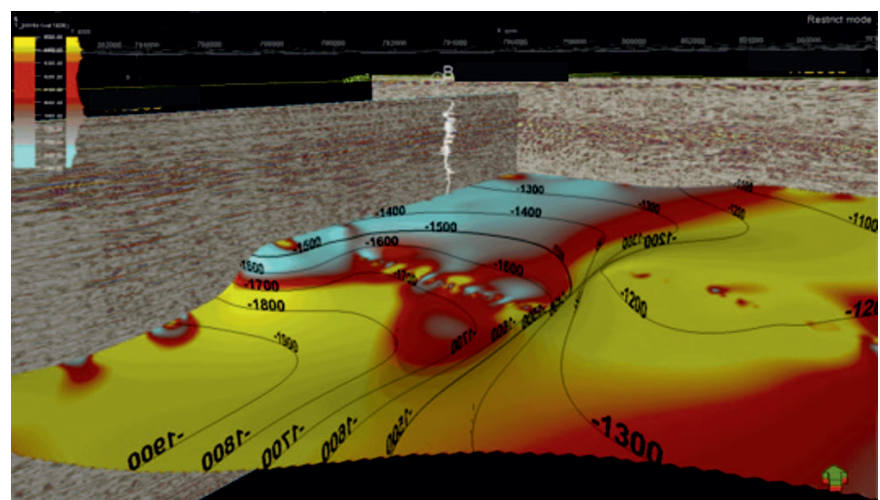

b)

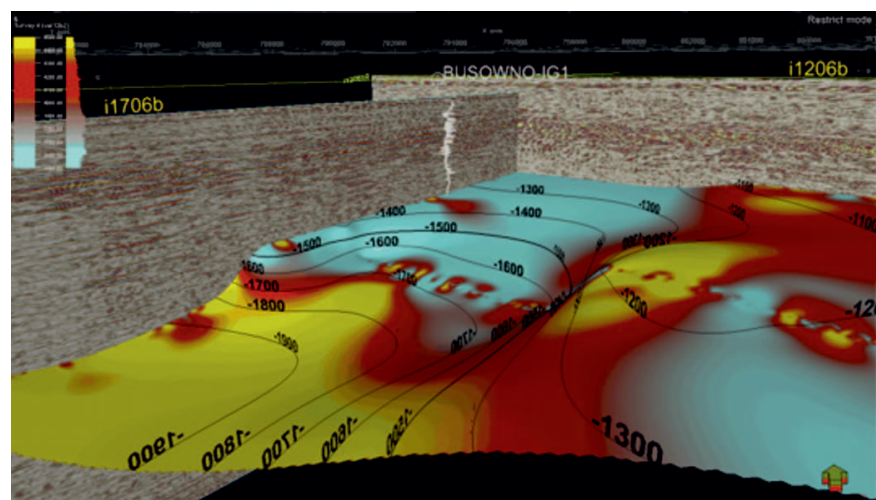

Rys. 17. Widok przestrzenny prędkości inwersyjnych dla stropu syluru na danych w wersji PSTM (a) oraz po modyfikacji spektralnej (b)

vel: $3560 \div 4500 \mathrm{~m} / \mathrm{s}$

a)

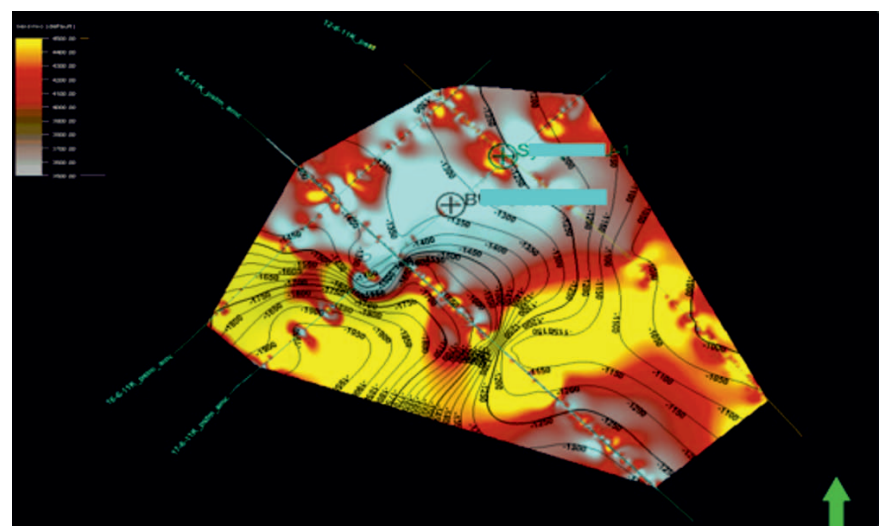

b)

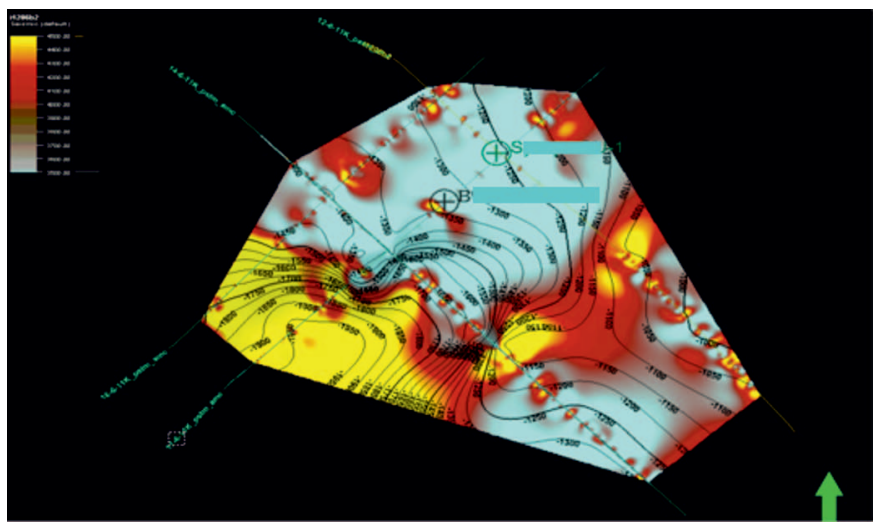

Rys. 18. Porównanie wyników inwersji sejsmicznej na danych w wersji PSTM (a) oraz po modyfikacji spektralnej (b) na tle mapy czasowej stropu syluru 

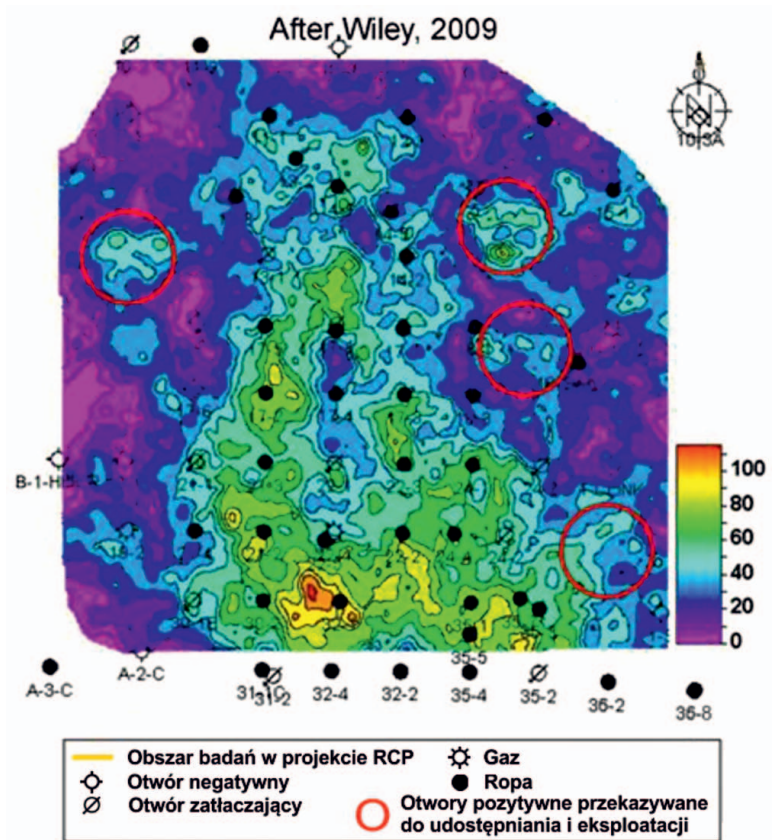
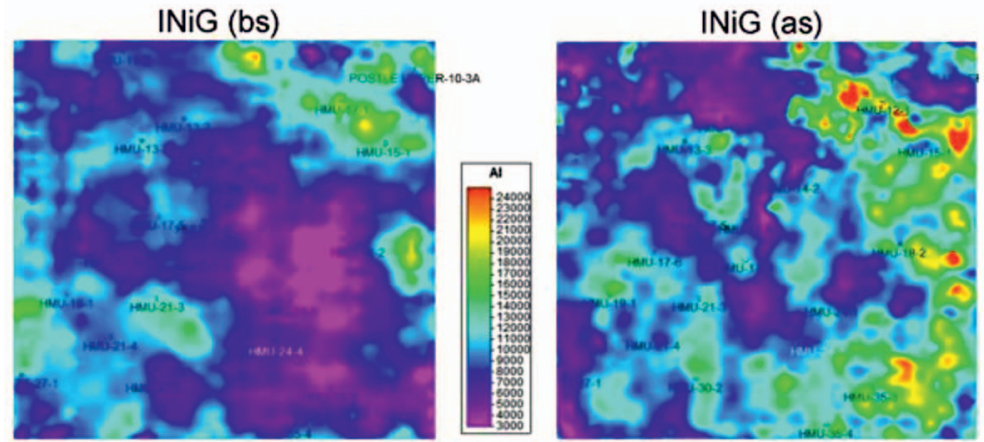

Rys. 19. Porównanie wyników inwersji sejsmicznej obliczonych na danych sejsmicznych przed (bs) i po (as) modyfikacji spektralnej z wynikami predykcji parametrów złożowych potwierdzonych danymi nowo odwierconych otworów w rejonie projektu Postle Field (według M.L. Wiley, 2009)

\section{Podsumowanie}

Śledząc bibliografię związaną z tematyką broadband seismic, prawie powszechnie zwraca uwagę brak rozważań natury teoretycznej, co nie jest związane z prostotą prezentowanego zagadnienia, a raczej z dość skomplikowaną strukturą zazwyczaj patentowych algorytmów i programów. W takiej sytuacji publikowane są wyniki wejściowe i po zastosowaniu danego rozwiązania. Taka prezentacja nie ułatwia analizy procedury obliczeniowej.
W prezentowanej publikacji ścieżka obliczeniowa jest przedstawiona jednoznacznie, podobnie zresztą jak wiele wyników pośrednich. Taki otwarty sposób objaśniania metodyki z jednej strony wynika z przekonania, że analiza obrazu spektralnego sejsmicznego pola falowego wnosi wiele nowych możliwości interpretacyjnych, a z drugiej strony z faktu, że została ona również opatentowana (patent polski nr 218109; U.S.A. Pat. No. 9,551,803) [3, 17].

Prosimy cytować jako: Nafta-Gaz 2017, nr 8, s. 531-550, DOI: 10.18668/NG.2017.08.01

Artykuł nadesłano do Redakcji 7.03.2017 r. Zatwierdzono do druku 23.05.2017 r.

\section{Literatura}

[1] Broadband Solutions. Geokinetics. First Break 2013, vol. 31, no. 10, s. 40 .

[2] Chadwick R.A., Williams G.A., White J.C.: High resolution imaging and characterization of a $\mathrm{CO}_{2}$ layer at the Sleipner $\mathrm{CO}_{2}$ storage operation. North Sea using time-lapse seismics. First Break 2016, vol. 34, nr 2, s. 77-85.

[3] Davis T.L., Jędrzejowska-Tyczkowska H., Żukowska K., Irlik I.: Geological Medium Exploration. Patent Nr U.S. 9,551,803, z dn. 24.01.2017.

[4] Denis M., Brem V., Pradalie F., Moinet F., Retailleau M., Langlois J., Bai B., Taylor R.: Can land broadband seismic be as good as marine broadband? The Leading Edge 2013, vol. 32, nr 11, s. 1382-1388.

[5] Duval G.: How broadband can unlock the remaining hydrocarbon potential of the North Sea. First Break 2012, vol. 30, nr 12, s. 85-91.

[6] Gaiser J., Verm R., Chaveste A.: Pseudo S-wave broadband response of $C$-waves after domain change. The Leading Edge 2013, vol. 32, nr 1, s. 50-62.

[7] Goodway B., Ronen S.: Introduction to this special section:
Offshore and onshore broadband seismology. The Leading Edge 2013, vol. 32, nr 11, s. 1354-1355.

[8] Jędrzejowska-Tyczkowska H.: Dynamic seismic velocity modeling. First Break 2011, vol. 29, nr 3, s. 73-79.

[9] Jędrzejowska-Tyczkowska H.: Niejawne aspekty procedur zwiększenia rozdzielczości i rozszerzenia zakresu częstotliwości sejsmicznego pola falowego. [W:] Rzeczpospolita tupkowa - Studium wiedzy o gazie tupkowym. Prace Naukowe INiG 2012, nr 183, s. 71-89.

[10] Jędrzejowska-Tyczkowska H.: Odtworzenie pożadanej rozdzielczości danych sejsmicznych $w$ aspekcie realizowanych zadań geologicznych. Prace Naukowe INiG 2012, nr 182, s. 57-63.

[11] Jędrzejowska-Tyczkowska H.: Renesans roli akwizycji w metodzie sejsmicznej w świetle poszukiwań niekonwencjonalnych złóż węglowodorów. Nafta-Gaz 2011, nr 11, s. 777-792.

[12] Jędrzejowska-Tyczkowska H.: The Impact of Phase Characteristics on Seismic Data Resolution. Second EAGE/SBGf Workshop 2014, 4-5 November, Copacabana, Rio de Janeiro, Brazil. 
[13] Jędrzejowska-Tyczkowska H.: The influence of disturbances and noise of normal distribution on the correctness of geological interpretation of seismic sections with increased resolution. Nafta-Gaz 2015, nr 12, s. 59-71, DOI: 10.18668/ NG2015.12.01.

[14] Jędrzejowska-Tyczkowska H., Davis T.L.: Wanted and unwanted effects of surface seismic data resolution improvements. First Break 2012, vol. 30, nr 9, s. 75-82.

[15] Jędrzejowska-Tyczkowska H., Sowiżdżał K.: Importance of seismic data resolution on geological results of multidisciplinary geophysical research including $3 D$ geological modelling. International Conference „Engineering and Telecommunications Technology", Moskwa 2014, Publisher IEEE Computer Society, Los Alamitos, CA, USA, s. 116-117.

[16] Jędrzejowska-Tyczkowska H., Sowiżdżał K.: Unconventional Reservoir Characterization - The need of Conventional Workflows Modification. SEG, D\&P FORUM, Integrated Geophysics for Unconventional Resources, Poland, Cracow, 7-11 July 2013.

[17] Jędrzejowska-Tyczkowska H., Żukowska K., Irlik I.: Sposób zwiększenia dokładności i głębokości rozpoznania ośrodka geologicznego na podstawie rejestrowanych drgań sejsmicznych. Patent nr 394446, z dn. 12.03.2014.

[18] Mandroux F., Ong B.S., Ting Ch.O., Mothi S., Huang T., Li Y.: Broadband, long-offset, full-azimuth, staggered marine acquisition in the Gulf of Mexico. First Break 2013, vol. 31, nr 6, s. 125-132.
[19] Mann J.: Broadband seismic imaging improves subsurface mapping of Santos basin pre-salt reservoirs. World Oil, September 2013, s. 33-38.

[20] Sheriff R.E.: Vocabulary of Geophysical Terms. Encyclopedic Dictionary of Exploration Geophysics. SEG 1973, Tulsa, Oklahoma.

[21] Vassallo M., Eggenberger K., Van Manen D.J., Özbek A., Watterson P.: Broadband and beyond with marine towed streamers. The Leading Edge 2013, vol. 32, nr 11, s. 1356-1365.

[22] Widess M.B.: How thin is a thin bed. Geophysics 1973, vol. 38, nr 6, s. 1176-1180.

[23] Wiley M.L.: Structural and Stratigraphic Controls on Morrow Sandstone Reservoir Distribution from 3-D Seismic Data, Postle Field. Texas County 2009, Oklahoma.

[24] Zhou Z., Cvetkovic M., Xu B., Fontana P.: Analysis of a broadband processing technology applicable to conventional streamer data. First Break 2012, vol. 30, nr 10, s. 77-82.

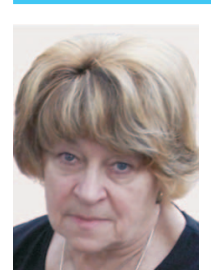

Prof. nzw. dr hab. inż. Halina JĘDRZEJOWSKA-TYCZKOWSKA

Instytut Nafty i Gazu - Państwowy Instytut Badawczy ul. Lubicz $25 \mathrm{~A}$

31-503 Kraków

E-mail: tyczkowska@inig.pl

\section{OFERTA}

\section{ZAKŁAD SEJSMIKI}

Zakres działania:

- $\quad$ interpretacja strukturalna i litofacjalna zdjęć sejsmicznych 2D i 3D

- $\quad$ przetwarzanie danych sejsmicznych 2D/3D Prestack i Postack

- $\quad$ migracja sejsmiczna MGF-K w wersji Prestack i Postack w domenie czasu i głębokości z uwzględnieniem anizotropii ośrodka typu VTI, TTI, HTI;

- $\quad$ interpretacja strukturalna i litofacjalna pomiarów sejsmicznych Prestack i Postack 2D oraz 3D;

- $\quad$ przetwarzanie i interpretacja pionowych profilowań sejsmicznych PPS 1C, 3C

- budowa modeli prędkościowych na podstawie analiz danych sejsmicznych i geofizycznych w domenie czasu i głębokości - konwersja czas-głębokość, migracja głębokościowa;

- $\quad$ interpretacja danych sejsmicznych 3D-3C oraz pomiarów sejsmiki otworowej PPS-3C

- $\quad$ konstrukcja map powierzchniowych - czasowych i głębokościowych;

- $\quad$ zwiększenie dokładności identyfikacji ośrodka geologicznego poprzez modyfikację charak terystyki widmowej zarejestrowanych danych sejsmicznych;

- $\quad$ poprawa rozdzielczości danych sejsmicznych Postack - dekompozycja spektralna;

- wieloatrybutowa charakterystyka ośrodka geologicznego;

- $\quad$ analizy sejsmiczne AVO, AVAZ:

- obliczanie inwersji symultanicznej oraz stochastycznej;

- $\quad$ wykonywanie modelowania sejsmicznego;

- $\quad$ identyfikacja anizotropii typu HTI w ośrodku geologicznym przy użyciu danych sejsmicznych i otworowych - określenie intensywności oraz azymutu anizotropii;

- obliczanie parametrów anizotropii typu VTI i HTI oraz określenie głównych kierunków szczelinowatości na podstawie wieloazymutalnego pomiaru PPS 3C i sejsmiki powierzchniowej:

- $\quad$ wyznaczanie poziomów zlożowych (bright, dim oraz sweet spot) na danych Prestack oraz Postack;

- $\quad$ zastosowanie metod geostatycznych do konstrukcji statycznych i dynamicznych modeli złóż węglowodorów;

- $\quad$ prognozowanie ciśnień porowych na podstawie danych sejsmicznych i geofizycznych.

P. o. Kierownika: mgr inż. Aleksander Wilk

Adres: ul. Bagrowa 1, 30-733 Kraków

Telefon: 126177480

Faks: 126531665

E-mail: aleksander.wilk@inig.pl

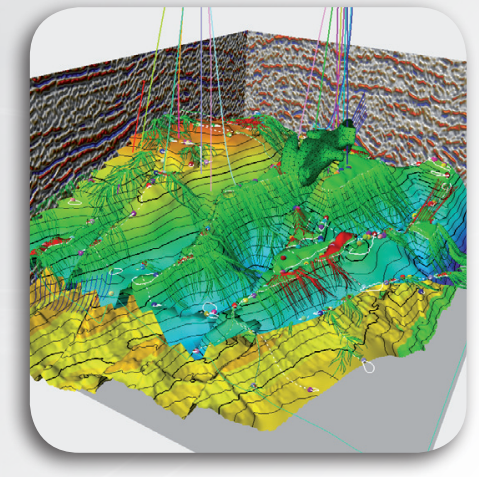

